Review Article

\title{
Physical Properties of Nanoparticles That Result in Improved Cancer Targeting
}

\author{
Randa Zein $\mathbb{D}^{1},{ }^{1}$ Wissam Sharrouf, ${ }^{2}$ and Kim Selting ${ }^{3}$ \\ ${ }^{1}$ University of Genoa, Department of Oral Diagnosis, Genoa, Italy \\ ${ }^{2}$ Lebanese University, Department of Oral Diagnosis, Beirut, Lebanon \\ ${ }^{3}$ Department of Veterinary Clinical Medicine, University of Illinois, Champaign-Urbana, IL, USA
}

Correspondence should be addressed to Randa Zein; appleclinic21@gmail.com

Received 2 February 2020; Revised 26 April 2020; Accepted 30 May 2020; Published 13 July 2020

Academic Editor: Thomas R. Chauncey

Copyright ( $\odot 2020$ Randa Zein et al. This is an open access article distributed under the Creative Commons Attribution License, which permits unrestricted use, distribution, and reproduction in any medium, provided the original work is properly cited.

The therapeutic efficacy of drugs is dependent upon the ability of a drug to reach its target, and drug penetration into tumors is limited by abnormal vasculature and high interstitial pressure. Chemotherapy is the most common systemic treatment for cancer but can cause undesirable adverse effects, including toxicity to the bone marrow and gastrointestinal system. Therefore, nanotechnology-based drug delivery systems have been developed to reduce the adverse effects of traditional chemotherapy by enhancing the penetration and selective drug retention in tumor tissues. A thorough knowledge of the physical properties (e.g., size, surface charge, shape, and mechanical strength) and chemical attributes of nanoparticles is crucial to facilitate the application of nanotechnology to biomedical applications. This review provides a summary of how the attributes of nanoparticles can be exploited to improve therapeutic efficacy. An ideal nanoparticle is proposed at the end of this review in order to guide future development of nanoparticles for improved drug targeting in vivo.

\section{Introduction}

The first discovery of enhanced permeability and retention (EPR) by Matsumura and Maeda [1] and coworkers, demonstrating the potential for accumulation of macromolecules by extravasation through fenestrated blood vessels in tumors, has opened the door for many attempts to produce a drug able to reach the tumor site [1]. A century has passed since this discovery and yet only 1 in 10 drugs gain Food and Drug Administration (FDA) approval, primarily due to the lack of efficacy in later stage clinical trials [2]. FDA-approved nanomedicines for cancer therapy include doxorubicin (Doxil/Caelyx) [1], daunorubicin (DaunoXome) [2] and paclitaxel (Abraxane) [3], all of which show a modest improvement in the overall survival of patients $[3,4]$.

Tumor vasculature is well characterized as hyperpermeable, immature, and with elevated interstitial fluid pressure, all of which are conducive to an EPR effect. This effect can vary significantly, not only among patients, but also across different tumor types and even changes for the same tumor over time [5].

An ideally designed NP should avoid clearance by the mononuclear phagocytic system, should remain in the blood circulation for a long time to ensure sufficient accumulation in the targeted tissues, should be internalized by the target tissue, and finally should have low toxicity. Modifying the physical properties of NPs such as size, charge, and shape, could result in changes in the therapeutic efficacy [6]. Two strategies for drug targeting are widely used: passive and active targeting (see Figure 1). Passive targeting is based on drug accumulation in tumor tissue due to the physical characteristics of both the drug carrier and the tumor architecture [7]. In contrast, active targeting is based on molecular ligand-receptor interactions and is only possible when the receptor and ligand come in close proximity (less than $0.5 \mathrm{~mm}$ ) after the drug has circulated through the blood and extravasated in the tumor tissue [7]. In vitro interactions of NP with cells might not correspond to their behavior in vivo [8]. Therefore, by gaining deeper insight into 


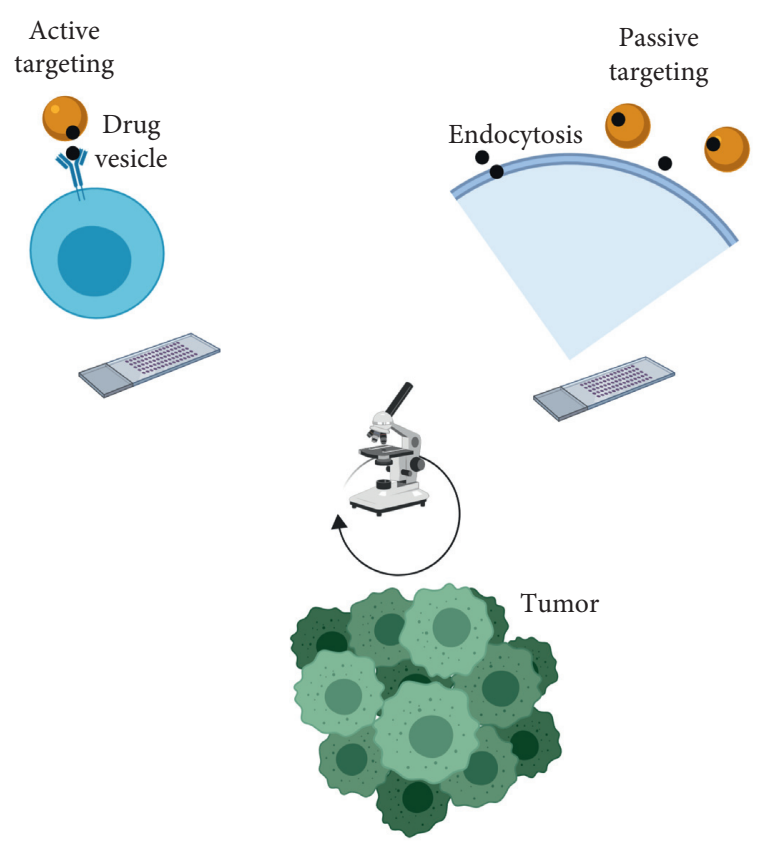

FIGURE 1: Active versus passive tumor targeting. In active targeting, the drug needs a receptor at the tumor surface, whereas in passive targeting, the drug enters the target cells passively.

interactions of NPs with cells and the tumor microenvironment, we may begin to maximize the potential of nanomedicine in cancer. This review will address physicochemical parameters affecting biodistribution and those affecting tumor uptake in order to propose characteristics of an ideal NP.

\section{Nanoparticles First Interaction in Body: Protein Corona and Biological Barriers}

Once introduced in the human body, NPs will face many obstacles before eventually interacting with the tumor including the protein corona and other biological barriers.

2.1. Protein Corona and NPs. Nanoparticles are being intensely researched as vehicles to deliver therapeutic drugs to a diseased site. It has become clear that slight changes in the physicochemical properties of NPs have significant biological implications. Most NPs that come into contact with biological materials are coated by a wide variety of proteins, which is named the "protein corona." One component of the NP corona (called opsonins) can enhance the NP uptake by the RES. Under physiologic conditions, the corona may alter the NP properties by masking its surface characteristics $[9,10]$. The exposure time in the blood circulation has been recognized as a key factor that shapes the NP biomolecular corona; furthermore, the new properties that are imparted to the NPs by the corona are the main factor that controls the distribution, nanotoxicity, and the therapeutic effect of NPs in the body [11] (Figure 2).

Some studies have suggested that the formation of the protein corona is an undesirable process; however, others have discussed the advantages of this formation, such as

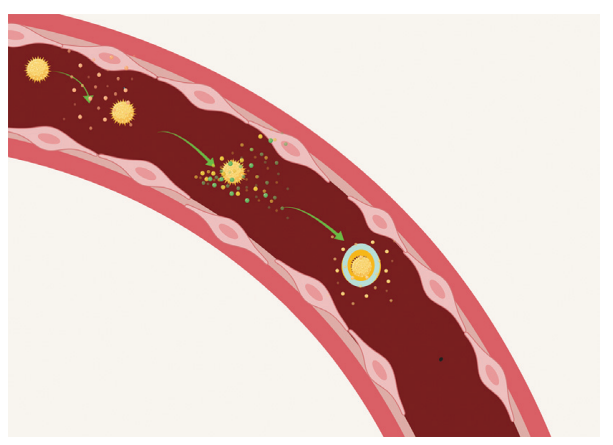

FIgURE 2: This figure shows how NPs are coated with proteins once they enter the blood circulation; after a short period of time, proteins came in close contact and form soft corona, and then a final hard protein corona is formed around the NPs containing a fingerprint specific for each individual and tumor.

reducing the cytotoxic effect, eliminating undesirable interactions with the immune system, and facilitating cellular internalization [12]. The protein corona might reduce the targeting capability of the NPs by shielding the recognition site of the targeting ligands from the receptors [13]. Different disease types can have different effects on the corona composition, because for every disease, there are different types of proteins secreted in the body, and these proteins may affect the corona composition around the NPs [14]. These considerations mean that patients with different types of cancer may have specific types of coronas [14]. This has led some authors to introduce a new concept for NP targeting called a "personalized protein corona" (PPC) [15], wherein precise information on corona composition is a must to produce optimum personalized nanomedicines for therapy and diagnosis of every type of cancer. Colapicchioni et al. [16] investigated whether the pathological alteration of plasma proteins influenced the protein corona. They incubated liposomes with the plasma taken from patients with confirmed breast, pancreatic, and gastric cancer. The NPs were then isolated by centrifugation, and they found that the hard corona varied between patients having the same disease. They concluded that individual or personalized NPs can reduce the undesirable side effect of medications. NPs in the blood can function as scaffolds that attract specific proteins from the plasma; this may be due to the fact that tumor antibodies appear early in the plasma of patients and these antibodies are specific for each patient and disease [16].

As was said before, a single change in the physical properties of NPs may change the composition of the protein corona. Treuel and Nienhaus [17] found that the composition of the corona was affected by the size of NPs. Proteins tend to accumulate more on larger-sized NPs $(100 \mathrm{~nm})$ than on smaller-sized NPs, whereas proteins with higher affinity tend to bind more to smaller NPs $(20 \mathrm{~nm})$ [17]. The nature of the protein corona could influence the NP-cellular interactions (internalization) since the corona is the first point of contact between the NPs and the tumor cells [17].

For example, immunoglobulin binding to the NPs is called particle opsonisation and as a consequence leads to a rapid receptor-mediated phagocytosis uptake [18]. 
Furthermore, a higher degree of protein coverage has been found on hydrophobic NPs, compared to similar-sized hydrophilic NPs [19].

The corona may also increase the targeting capability of the NPs, if the binding site of the NPs is governed by the protein corona itself. In order to exploit this mechanism, it is necessary to understand which proteins deliver the NPs to which location [20]. As one example, Aoyama et al. found that the cluster in the protein corona could play a key role in the stealth effect by inhibiting the cellular uptake of silver NPs by phagocytic cells (macrophages) [21]. Furthermore, the plasma-protein corona suppressed the macrophage uptake more efficiently than the serum-protein corona due to the higher amount of cluster plasma [21].

At the present time, a large gap still exists in the understanding of the basic laws that govern the protein corona formation. Since the corona is the first interaction between the NPs and the tumor, it is essential in the future to establish a mathematical model to predict NP-surface interactions. What is clear now is that the final corona around the $\mathrm{NP}$ contains a so-called "fingerprint," which is related to the type of tumor, the physical characteristics of the NPs, and the stage of the tumor.

2.2. NPs and Biological Barriers. Once administered, NPs may encounter many obstacles in reaching the target site. For intravenously administered NPs, the first barrier is the reticuloendothelial system (RES) consisting of the liver and spleen, which rapidly removes many particles from the circulation. In addition, the endothelium of blood vessels within the target tissues is also a barrier [22]. In healthier tissue, NPs cannot cross the endothelium of the blood capillaries, whereas in some pathological conditions, for example, inflammation or cancer, the cells of the endothelium lose the integrity of their connections due to the influence of proinflammatory cytokines. The gap between the endothelial cells is increased so that the NPs can extravasate from the vessel system into the diseased tissue. Therefore, the leakiness in tumor vasculature leads to better penetration of the NPs and then retention of the NPs in the tumor bed in a process known as "enhanced permeability and retention" [23].

If the NPs succeed in escaping from the blood capillaries, they face a third barrier in the interstitial space composed of collagen and elastic fibers composed of glycosaminoglycans and other proteins that form the extracellular matrix (ECM). In diseases such as liver fibrosis and neoplasia, the collagen content is higher than that of normal tissues [24]. Because of this, the excessive rigidity and increased interstitial pressure of the ECM pose a barrier to NP transport from the capillaries to the target cells $[24,25]$.

Some NPs will release their contents spontaneously once they have extravasated into the tumor, while other release their contents in response to a stimulus such as hyperthermia, laser exposure, or magnetic fields. The released drug will interact as usual with nearby cells. Because NPs cannot simply enter the target cells via diffusion, the next barrier for NPs is the plasma membrane. The mechanisms by which NPs are internalized by the target cells include pinocytosis, phagocytosis, or endocytosis [3].

The mechanism of internalization depends on the NP properties as well as the size and type of cells involved. If NPs are released from endosomes and lysosomes, they can diffuse in the cytoplasm and could enter the cell nucleus. Usually the membrane of the nucleus does not allow entry of NPs larger than $9 \mathrm{~nm}$, providing yet another barrier [26].

\section{Physicochemical Properties of Nanoparticles Affecting Biodistribution}

The two most commonly studied parameters that affect NPs biodistribution are the size and the shape of nanoparticles; however, the charge and the coating surface of the NPs may play some role in biodistribution.

3.1. Effect of NP Size on Tissue Biodistribution. The therapeutic effect of NPs can be limited by their nonspecific systemic biodistribution, which can cause systemic toxicity and lead to reduced concentrations of drug delivered into the tumor (less than 5\%). In order to enable diverse application of NPs, it is crucial to study the biodistribution of different-sized NPs, to gain a clear idea of what size NPs to use and for what kind of treatment.

Sonavane et al. [27] evaluated the biodistribution of AuNPs with different size $(15,50,100$, and $200 \mathrm{~nm})$ after intravenous administration and found that the accumulation of NPs in various tissues was size-dependent; the smallest NPs $(15 \mathrm{~nm})$ showed the highest accumulation in organs (liver, lung, spleen, and kidney). Only the smallest NPs $(15 \mathrm{~nm})$ were able to cross the blood brain barrier $[27,28]$.

The size of the NPs will also affect their clearance from the circulation. Renal clearance is very rapid for particles with diameters smaller than $5-6 \mathrm{~nm}$, while clearance by the liver and the spleen is rapid for larger particles, above $200 \mathrm{~nm}$ in diameter [29]. Particles with sizes $200 \mathrm{~nm}$ or larger are mostly removed by the mononuclear phagocytic system (MPS, also known as the RES), mediated by cells in the liver, spleen, and bone marrow [30]. At $100 \mathrm{~nm}$, NPs have poor diffusion within the dense collagen matrix of the interstitial space, thus resulting in poor penetration into the tumor parenchyma and restricted NP accumulation around tumor blood vessels [30].

Cytotoxicity is also affected by NP size; the smaller the size, the greater the toxicity. Gao et al. [31] measured the cytotoxicity of different NPs with sizes ranging from $8 \mathrm{~nm}$ to $37 \mathrm{~nm}$ and found that the $8 \mathrm{~nm}$ NPs showed more cytotoxicity compared to the larger size NPs [31]. In Table 1, we summarize how variation in the size NPs affects their biodistribution (Figure 3).

3.2. Effect of NPs Shape on Biodistribution. While NP size is the principal parameter that affects macrophage uptake, the shape of the NP also plays a major role in enhancing or inhibiting the uptake and biodistribution [36]. 
TABLE 1: Biodistribution of NPs with different sizes in the liver, spleen, tumor, kidney, brain, and lung.

\begin{tabular}{|c|c|c|c|c|c|c|c|c|}
\hline Authors & NP size & Liver & Spleen & Tumor & Kidney & Brain & Lung & Other \\
\hline Li et al. [32] & $\begin{array}{l}6.2,24.3,42.5 \\
\text { and } 61.2 \mathrm{~nm} \\
\text { mean diameter }\end{array}$ & $\begin{array}{c}\text { High } 42.5 \text { and } \\
\quad 61.2 \mathrm{~nm}\end{array}$ & $\begin{array}{l}\text { High } 42.5 \\
\text { and } \\
61.2 \mathrm{~nm}\end{array}$ & 6.2 and $24.3 \mathrm{~nm}$ & $\begin{array}{l}6.2 \text { and } \\
24.3 \mathrm{~nm}\end{array}$ & $\begin{array}{l}6.2 \text { and } \\
24.3 \mathrm{~nm}\end{array}$ & $\begin{array}{l}6.2 \text { and } \\
24.3 \mathrm{~nm}\end{array}$ & \\
\hline $\begin{array}{l}\text { Sonavane et al. } \\
\text { [27] }\end{array}$ & $\begin{array}{l}15,20 \text {, and } \\
100 \mathrm{~nm}\end{array}$ & High $\%$ for all & $\begin{array}{l}\text { High } \% \\
\text { for all }\end{array}$ & $15>20>100 \mathrm{~nm}$ & High $\%$ for all & $\begin{array}{l}\text { (i) } 15 \mathrm{~nm} \\
\text { low } \% \\
\text { (ii) } 20 \mathrm{~nm} \\
\text { absent } \\
\text { (iii) } 100 \mathrm{~nm} \\
\text { absent }\end{array}$ & $\begin{array}{l}\text { (i) } 15 \text { and } \\
20 \mathrm{~nm} \text { high } \\
\% \\
\text { (ii) } 100 \mathrm{~nm} \\
\text { low } \%\end{array}$ & $\begin{array}{l}\text { (i) } 15 \mathrm{~nm} \\
\text { absent } \\
\text { (ii) } 20 \\
\text { and } \\
100 \mathrm{~nm} \\
\text { traces }\end{array}$ \\
\hline Tate et al. [33] & 20 and $100 \mathrm{~nm}$ & $\begin{array}{c}\text { High } \\
20 \mathrm{~nm}<100 \mathrm{~nm}\end{array}$ & $\begin{array}{l}\text { High for } \\
\text { all }\end{array}$ & $20>100 \mathrm{~nm}$ & $20<100 \mathrm{~nm}$ & Traces & High & - \\
\hline $\begin{array}{l}\text { Takeuchi et al. } \\
\text { [34] }\end{array}$ & $\begin{array}{l}20,50 \text {, and } \\
100 \mathrm{~nm}\end{array}$ & High $\%$ for all & $\begin{array}{l}\text { High for } \\
\text { all }\end{array}$ & $20>50>100 \mathrm{~nm}$ & $\begin{array}{l}20,50 \text {, and } \\
100 \mathrm{~nm} \\
\text { Moderate }\end{array}$ & $\begin{array}{l}\text { (i) } 20 \mathrm{~nm} \\
\text { moderate } \% \\
\text { (ii) } 50 \text { and } \\
100 \mathrm{~nm} \\
\text { absent }\end{array}$ & Moderate & Traces \\
\hline $\begin{array}{l}\text { Dziendzikowska } \\
\text { et al. [35] }\end{array}$ & $\begin{array}{c}-20 \text { and } \\
200 \text { nm silver } \\
\text { NP(AgNPs) }\end{array}$ & $\begin{array}{l}\text { (i) } 20 \mathrm{~nm} \text { high } \% \\
(24 \mathrm{~h}) \\
\text { (ii) } 200 \mathrm{~nm} \\
\text { moderate } \%\end{array}$ & $\begin{array}{l}\text { (i) } 20 \mathrm{~nm} \\
\text { high }(7 \\
\text { days) } \\
\text { (ii) } \\
200 \mathrm{~nm} \\
\text { low }\end{array}$ & Absent for both & $\begin{array}{l}\text { (i) High \% } \\
20 \mathrm{~nm} \\
\text { (ii) low \% } \\
200 \mathrm{~nm}\end{array}$ & $\begin{array}{l}\text { (i) } 20 \mathrm{~nm} \\
\text { Moderate \% } \\
\text { (ii) } 200 \mathrm{~nm} \\
\text { low } \%\end{array}$ & $\begin{array}{l}\text { (i) } 20 \mathrm{~nm} \\
\text { high } \% \\
\text { after } 7 \text { days } \\
\text { (ii) } 200 \mathrm{~nm} \\
\text { low } \%\end{array}$ & $\begin{array}{l}\text { (i) } 20 \mathrm{~nm} \\
\text { traces } \\
\quad(\mathrm{ii}) \\
200 \mathrm{~nm} \\
\text { absent }\end{array}$ \\
\hline
\end{tabular}

It can be concluded that the smaller the size of NPs, the more accumulation found in the spleen, liver, and lung than the kidney; a moderate concentration could accumulate in the tumors and only a low quantity is able to cross the blood brain barrier to accumulate in the brain, whereas the higher the size $(+100 \mathrm{~nm})$, the greater distribution in the liver, kidney, and spleen. None of these studies found a good distribution in the brain and only traces of large diameters were found in the tumor.

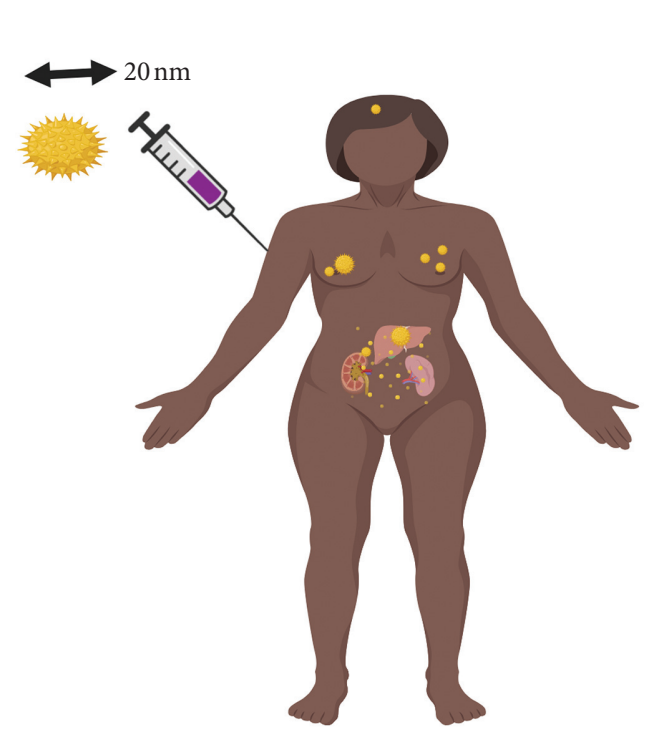

(a)

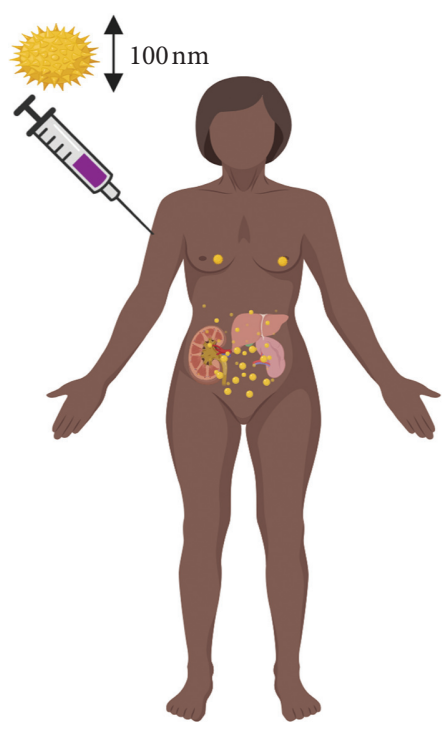

(b)

FIGURE 3: Effect of varying the NPs size on tissue biodistribution of patient with breast cancer. A $100 \mathrm{~nm}$ NPs mostly distribute in the liver, spleen, and kidney, and traces could be found in the breast, whereas, for $20 \mathrm{~nm}$ NPs, they mostly distribute in the kidney, spleen, and liver; a moderate amount is able to reach the breast tumor and traces were found in the brain.

When NPs come into contact with macrophages, the contact angle that initially occurs subsequently dictates the rate of internalization. A particle that aligns with its long axis parallel to the cell membrane would be internalized more slowly than NPs that align with the short axis parallel to the cell membrane. The rod-shaped NPs are internalized more quickly when they are perpendicular to the axis of the cell $\theta=90^{\circ}$. When the NPs are tangential to the macrophage membrane, the rate of internalization decreases (Figure 4). The rate of spherical NP internalization is independent of $\theta$ due to their symmetrical shape $[38,39]$.

Thus, it can be concluded that the size, shape, and the aspect ratio are the major factors that affect the macrophage uptake of NPs. 


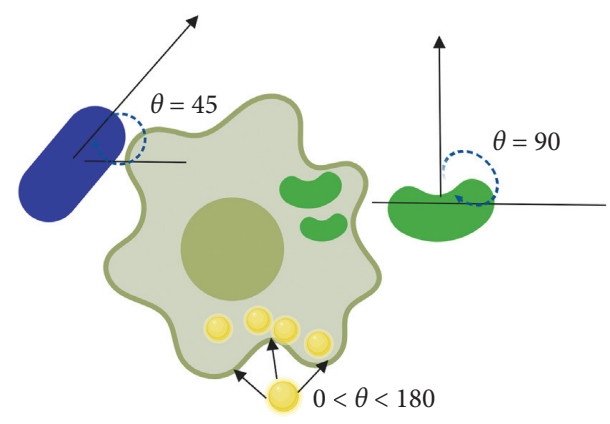

Figure 4: Effect of contact angle on the internalization efficacy. Nanoparticles having a prolate ellipsoid morphology (major axis $0.35-2 \mathrm{~nm}$, minor axis $0.2-2 \mathrm{~nm}$ ) had the slowest internalization rate and the highest attachment rate in comparison to spheroidal morphology (radius $0.26-1.8 \mathrm{~nm}$ ) and oblate ellipsoidal nanoparticles (major axis $0.35-2.5 \mathrm{~nm}$, minor axis $0.2-2 \mathrm{~nm}$ ) [37].

3.3. Effect of Nanoparticle Charge on Biodistribution. The surface charge on NPs is usually measured as the zeta potential $(\xi)$. Positively charged NPs $(\xi>10 \mathrm{mV})$ will induce serum protein aggregation, negatively charged NPs $(\xi<-10 \mathrm{mV})$ exhibit strong reticuloendothelial system (RES) uptake, and neutral NPs (within $\pm 10 \mathrm{mV}$ ) exhibit the least RES interaction and the longer circulation time [40].

Negatively charged NPs have a higher diffusion coefficient and penetrate the skin more rapidly, whereas positively charged NPs show the opposite behavior [27]. The potential charge effect could act as a repulsive or attractive force between the tissue surface and negatively or positively charged NPs, respectively. Therefore, Levchenko et al. concluded that neutrally charged NPs could be a better choice to eliminate the influence of surface charge [41].

It seems that the distribution of NPs in the kidney is not affected by the NP charge [42]. Positively charged NPs tend to accumulate more in the lungs than in other tissues. This is probably due to their ability to form aggregates by interacting with blood cells by electrostatic interactions and then these aggregates becoming entrapped in small capillaries in the lung [43].

Hepatic clearance can be influenced by the NP surface charge. NPs with high negative $(<-10 \mathrm{mV})$ or positive $(>10 \mathrm{mV})$ surface charge were efficiently cleared by the liver Kupffer cells from the blood circulation [44]. Another study found that NPs with $\xi<-40 \mathrm{mV}$ showed more than $90 \%$ clearance in $10 \mathrm{~min}$ compared to $<10 \%$ clearance for the neutral NPs $(\xi \pm 10 \mathrm{mV})$ and also increased liver uptake $(60 \%$ ID versus $<20 \%$ ID in 1 hour) [41]. In Table 2, we summarize the effect of NPs charge on tissue biodistribution.

3.4. Nanoparticles Surfactants and Biodistribution. NPs deployed in vivo can be protected from the immune system using various types of coating. Polyethylene glycol (PEG) has been used widely because it is biocompatible, chemically inert, and soluble in water and organic solvent [48]. PEG can also reduce phagocytic uptake, thereby prolonging the halflives of NPs in a mechanism called the stealth effect [49]. PEGylated NPs generally accumulate in the liver at one-half to one-third of the amount compared to non-PEGylated NPs [50] and gave a significant reduction of accumulation in the spleen, liver, and pancreas [51]. Similarly, when coating NPs with other types of coating such as breviscapine (BVP), researchers found that the NPs were mainly distributed in the liver, spleen, heart, and brain [52].

Despite the advantages of using PEG as coating, several new reviews describe the immunogenic properties of PEG which is characterized by the production of antibodies against PEG after the first injection of PEG-NPs. This causes accelerated blood clearance $(\mathrm{ABC})$ after the second injection [53-55]. One possible approach to reduce the immunological issues is to use immunosuppressive agents specific against PEG. For example, Tung et al. developed hybrid antibodies that can selectively deliver PEGylated medicine to the target cells [56]. Another strategy is the use of novel hydrophilic polymers other than PEG including BVP, polymeric NP, Poly (hydroxyethyl-L-asparagine), protein polymer, poly (amino acid) based stealth liposome [55], and zwitterionic polycarboxybetaine [57-60].

Many factors affect the PEGylation of NPs including the PEG polymer identity, the composition, density, hydrophobicity, and the nature of the proteins. These criteria should be properly regulated and adapted to avoid unfavorable effects of PEGylation [61]. NPs coated with lower molecular weight PEG were eliminated quickly from circulation [61].

In Table 3, we summarize the effect of using different types NPs coating on biodistribution.

\section{Physicochemical Properties of NPs Affecting Tumor Penetration}

The physicochemical properties of NPs (size, shape, charge, and surface coating) influence both tissue biodistribution and tumor uptake. Some properties play a major role on biodistribution and a minor role in tumor uptake. Furthermore, some properties are more pronounced in vitro than in vivo. In this part, we will discuss each property and how it may affect the tumor uptake.

4.1. Effect of Nanoparticles Size on Tumor Penetration. Intravenously administered NPs should be able to circulate in the bloodstream for a long time to have a good chance of reaching the tumor vasculature and then extravasating into the tumor tissue. Additionally, these NPs should not cross the vessel walls in normal tissues thereby causing adverse effects. As the pore size of normal vessels is between 6 and $12 \mathrm{~nm}$, this would suggest that nanoparticles should be larger than that size [67]. The primary design requirement is that NPs should be able to pass through the pores of the leaky tumor vessels but not the pores of the normal vessels. The pores of the tumor vessels are generally between 40 and $200 \mathrm{~nm}[28]$.

The next consideration is the interaction between NPs and the openings in the tumor vessel wall. There are three kinds of interactions: hydrodynamic interactions due to forces induced by the motion of the particles within the fluid 
TABLE 2: Effect of different NPs charges on tissue biodistribution: charged NPs are cleared rapidly by the immune system.

\begin{tabular}{|c|c|c|c|c|}
\hline Authors & NPs type & Charge & Uptake & Biodistribution \\
\hline $\begin{array}{l}\text { Xiao et al. } \\
{[44]}\end{array}$ & $\begin{array}{l}\text { PEG-micellar } \\
\text { nanoparticles }\end{array}$ & $\begin{array}{c}\text { Surface charge: high } \\
\text { negative }(<-10 \mathrm{mV}) \text { and } \\
\text { high positive }\end{array}$ & $\begin{array}{l}\text { High uptake by slightly } \\
\text { negative charged NPs }\end{array}$ & All charged NPs cleared by the Kupffer cells \\
\hline $\begin{array}{l}\text { He et al. } \\
{[45]}\end{array}$ & Polymeric NPs & $\begin{array}{l}\text { Negative }(-10 \mathrm{mV}) \\
\text { neutral and positive } \\
\text { charge }(+35 \mathrm{mV})\end{array}$ & $\begin{array}{l}\text { High uptake of slight } \\
\text { negative charged NP }\end{array}$ & Liver $>$ spleen $>$ lung $>$ tumor $>$ kidney $>$ blood \\
\hline $\begin{array}{l}\text { Walczak } \\
\text { et al. [46] }\end{array}$ & $\begin{array}{l}\text { Polystyrene NPs } \\
50 \mathrm{~nm}\end{array}$ & $\begin{array}{c}\text { Negative }(-7,7 \mathrm{mV}) \\
\text { positive NPs and neutral }\end{array}$ & $\begin{array}{l}\text { High uptake of negatively } \\
\text { charged NPs than the } \\
\text { neutral and positive one }\end{array}$ & Kidney $>$ heart $>$ stomach $>$ small intestine \\
\hline $\begin{array}{l}\text { Verma et al. } \\
\text { [47] }\end{array}$ & $\begin{array}{l}\text { Encapsulated } \\
\text { paclitaxel }\end{array}$ & Negative pectin NPs & 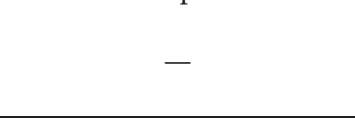 & $\begin{array}{l}\text { (i) Major accumulation in } \\
\text { liver }>\text { kidney }>\text { lung }>\text { spleen } \\
\text { (ii) Tissue prolonged plasma retention }\end{array}$ \\
\hline
\end{tabular}

TABLE 3: Effect of NPs coating on tissue biodistribution.

\begin{tabular}{|c|c|c|c|}
\hline Authors & Nanoparticle & Coating added & Distribution \\
\hline $\begin{array}{l}\text { Zhang et al. } \\
{[60]}\end{array}$ & Gold NPs & $\begin{array}{l}\text { Zwitterionic } \\
\text { polycarboxybetaine (PCB) }\end{array}$ & $\begin{array}{l}\text { PK behavior was unchanged, no antiuricase detected, no anti- } \\
\text { PCB antibodies detected }\end{array}$ \\
\hline $\begin{array}{l}\text { Rodriguez } \\
\text { et al. [62] }\end{array}$ & $160 \mathrm{~nm}$ nanobeads & CD47 “self” peptides & $\begin{array}{l}\text { Prolonged drug circulation by delaying phagocytic clearance by } \\
\text { the liver and spleen }\end{array}$ \\
\hline $\begin{array}{l}\text { Kreuter et al. } \\
\text { [63] }\end{array}$ & $\begin{array}{l}\text { poly(butyl } \\
\text { cyanoacrylate) } \\
\text { nanoparticles }\end{array}$ & Polysorbate 80 & enhanced drug delivery beyond the blood-brain barrier \\
\hline $\begin{array}{l}\text { Parodi et al. } \\
\text { [64] }\end{array}$ & $\begin{array}{l}\text { Nanoporous silicon } \\
\text { particles (NPS) }\end{array}$ & $\begin{array}{l}\text { Membranes purified from } \\
\text { white blood }\end{array}$ & Prolonged circulation time \\
\hline & Polymeric nanoparticles & Erythrocyte membrane & \\
\hline $\begin{array}{l}\text { Romberg et al. } \\
\text { [55] }\end{array}$ & Liposome & $\begin{array}{l}\text { Poly(hydroxyethyl-L- } \\
\text { asparagine) (PHEA) }\end{array}$ & $\begin{array}{c}\text { Longer blood circulation times than PEG liposomes. The } \\
\text { second injection less rapidly cleared from the circulation than } \\
\text { the second dose of PEG liposomes }\end{array}$ \\
\hline Lila et al. [66] & Liposome & Polyglycerol (PG) & $\begin{array}{l}\text { Reduced effect of } \mathrm{ABC} \text { when using polyglycerol compared to } \\
\text { PEG }\end{array}$ \\
\hline
\end{tabular}

medium; steric interactions due to collisions of the particles with the wall; and electrostatic interactions due to attraction or repulsion between charged particles and the negatively charged glycocalyx on the surface of the vessel wall [68-70].

These types of interaction are controlled by the ratio between the sizes of the particles and the size of the openings in the vessel wall. When this ratio is small, transport is facilitated, whereas the transport of particles that approach the size of the openings is hindered and the particles are unable to pass through the wall [35]. Most of the studies confirm that the smaller the NPs size, the greater the likelihood of penetrating the tumor [71-74].

Different techniques can be used to alter the NP size. Wong et al. proposed a multistage system where $100 \mathrm{~nm}$ NPs (QDGelNPs) with a core composed of gelatin and a surface covered with quantum dots (QDs) "shrink" to $10 \mathrm{~nm}$ nanoparticles after extravasation from leaky regions of the tumor vasculature. Protease enzymes in the tumor degrade the $100 \mathrm{~nm}$ gelatin NPs, releasing smaller $10 \mathrm{~nm}$ NPs from their surface [75]. Tong et al. developed photo-switchable NPs to enhance penetration. By triggering the NPs (spiropyran and lipid: SP-C9 NPs) with UV light (365 nm, intensity $=1 \mathrm{~mW} / \mathrm{cm}^{2}$ ), they underwent a reversible size change from $150 \mathrm{~nm}$ down to $40 \mathrm{~nm}$. Consequently, the photo-switching could allow the fluorescence to increase and the release of drugs inside the cells [76].

By referring to Table 1 (study of the NPs size biodistribution) and Table 4 (NPs size effect on tumor uptake), it can be concluded that there is a strong need to develop nanomedicines with tailorable sizes and physicochemical properties to target the tumor microenvironment for effective delivery into deep tumors and limited extravasation in normal tissues for enhanced therapeutic efficiency. The variation of the size of NPs presents a bell-shaped curve with regard to tumor accumulation (extravasation within the tumor), where smaller sizes (below $80 \mathrm{~nm}$ ) are not effective and larger sizes are also not suitable [78]. Similarly, the tumor penetration (movement within the tumor) of NPs also shows a bell-shaped curve, where the maximum NP penetration is less than $20 \mathrm{~nm}$ and may even be better for smaller sizes (between 2 and $15 \mathrm{~nm}$ ) [70, 73, 80]. Hence a conflict might exist between these two concepts; the best tumor accumulation due to the EPR effect requires a NP size between 100 and $150 \mathrm{~nm}$, while the best penetration requires a smaller NP size less than $12 \mathrm{~nm}$. To address this discrepancy, different techniques have been recently tested including the programmable loaded NP [76] and the photoswitchable NPs discussed above [75]. 
TABLE 4: Effect of NPs size on tumor penetration: the smaller the size, the higher the probability of tumor uptake.

\begin{tabular}{|c|c|c|c|c|}
\hline Author & Nanoparticle type & Nanoparticle size & Tumor type & Tumor penetration efficacy \\
\hline $\begin{array}{l}\text { Cabral et al. } \\
{[71]}\end{array}$ & $\begin{array}{c}\text { Drug loaded polymeric } \\
\text { micelles }\end{array}$ & $\begin{array}{c}30,50,70 \\
100 \mathrm{~nm}\end{array}$ & $\begin{array}{l}\text { Two cancer type (high and } \\
\text { low permeable) }\end{array}$ & Only $30 \mathrm{~nm}$ penetrate poorly permeable cancer \\
\hline $\begin{array}{l}\text { Ezealisiji and } \\
\text { Okorie [72] }\end{array}$ & Silver NPs & $\begin{array}{l}22,58,76 \\
378 \mathrm{~nm}\end{array}$ & $\begin{array}{l}\text { Dermatological } \\
\text { application }\end{array}$ & $\begin{array}{c}22 \mathrm{~nm} \text { exhibit the highest cumulative amount } \\
\text { (penetration) }\end{array}$ \\
\hline $\begin{array}{l}\text { Arvizo et al. } \\
{[77]}\end{array}$ & $\begin{array}{l}\text { Gold NPs (without any } \\
\text { surface modification) }\end{array}$ & $5,10,20 \mathrm{~nm}$ & $\begin{array}{l}\text { Human umbilical vein } \\
\text { endothelial cells }\end{array}$ & $\begin{array}{c}20 \mathrm{~nm} \text { Maximum effect anti-angiogenic } \\
\text { effect(VFGF inhibition) }\end{array}$ \\
\hline $\begin{array}{l}\text { Peretz et al. } \\
{[78]}\end{array}$ & Gold nanoparticles & $\begin{array}{l}15,30,90 \\
150 \mathrm{~nm}\end{array}$ & $\begin{array}{l}\text { Head and neck cancer } \\
\text { cells }\end{array}$ & $\begin{array}{l}15 \mathrm{~nm} \text { best binding capacity to cancer cells \& } \\
90 \mathrm{~nm} \text { is optimal for cell targeting and tumor } \\
\text { accumulation }\end{array}$ \\
\hline $\begin{array}{l}\text { Popović et al. } \\
\text { [73] }\end{array}$ & Quantum dots & $12,60,125 \mathrm{~nm}$ & Melanoma in mouse & Rapid penetration for $` 12 \mathrm{~nm} \mathrm{NP}$ \\
\hline $\begin{array}{l}\text { Sonavane et al. } \\
\text { [27] }\end{array}$ & Gold nanoparticles & $\begin{array}{l}15,50,100 \\
200 \mathrm{~nm}\end{array}$ & $\begin{array}{l}\text { Mice (different organ), } \\
\text { intravenous } \\
\text { administration }\end{array}$ & $\begin{array}{l}15 \mathrm{~nm} \text { wide organ distribution, only } 15 \text { and } \\
50 \mathrm{~nm} \text { pass blood brain barrier }\end{array}$ \\
\hline $\begin{array}{l}\text { Huang et al. } \\
\text { [79] }\end{array}$ & $\begin{array}{l}\text { PVP-coated iron oxide } \\
\text { nanoparticles (PVP- } \\
\text { IOs) }\end{array}$ & $37-120 \mathrm{~nm}$ & Hepatic lesion in mouse & $37 \mathrm{~nm}$ greatest cellular uptake \\
\hline $\begin{array}{l}\text { Hemant et al. } \\
\text { [28] }\end{array}$ & Gold NPs & $\begin{array}{l}1 \text { to } 125 \mathrm{~nm} \\
\text { (intravenous) }\end{array}$ & Different pore size & Rapid penetration for ' $12 \mathrm{~nm} \mathrm{NP}$ \\
\hline $\begin{array}{l}\text { Huang et al. } \\
{[80]}\end{array}$ & $\begin{array}{l}\text { Gold nanoparticles } \\
\text { (AuNPs) }\end{array}$ & $2,6,15 \mathrm{~nm}$ & Breast cancer cells & $\begin{array}{l}2 \text { and } 6 \mathrm{~nm} \text { Maximum tumor uptake and } \\
\text { permeability. } 2 \& 6 \mathrm{~nm} \text { found in nucleus and } \\
\text { cytoplasm whereas } 15 \mathrm{~nm} \text { only in cytoplasm }\end{array}$ \\
\hline
\end{tabular}

\subsection{How Important Is the Size in Determining the Tissue} Penetration? The behavior of the NPs in contact with the cell membrane was studied in detail by Islam et al. in order to elucidate the effect of particle size that came into contact with the cells; they developed a model which enabled multiscale simulations under both diffusion and advection (horizontal flow) conditions (see Figure 5) [81]. They found a nonlinear relationship between tissue penetration and cellular uptake; this would suggest that cellular uptake is not determined by the probability of the NPs to be captured by the tumor surface, but by other factors including the likelihood of collisions and cell-particle interactions. They concluded that particle-size effect may dominate in a cellfree system in the absence of cell-particle interactions, and this effect is more pronounced in vitro. On the other hand, in vivo studies have shown that particle-cell interactions may moderate the particle-size effect, which might be the primary determinant of tissue penetration [81].

\subsection{Effect of Nanoparticles Shape on Tissue Penetration.} Nanoparticles can have different shapes, including filamentous, spherical, rod-like, or discoidal. Different techniques can be used to create a specific shape, including jet and flash imprint lithography (J-FIL) [50], film stretching, and nanofabrication processes [82, 83].

Filamentous nonmaterial (e.g., potato virus X) has been reported to have superior tumor-homing and pharmacokinetic properties compared to spherical particles [76]. Similarly, Champion et al. [84] compared different NP shapes; they concluded that elongated particles with a higher aspect ratio (i.e., the ratio of length to the width of NPs) are less prone to removal by the immune system [8]. In addition, elongated particles exhibited longer blood circulation times and avoided phagocytosis, depending on the angle of contact when they encounter macrophages [84].

Filamentous NPs (filomicelles) persisted in the circulation longer than spherical particles. When they are PEGylated (i.e., coated with polyethylene-glycol), this effect of filomicelles was further enhanced. Filomicelles have been shown to enter cells under static incubation conditions [84].

Table 5 summarizes how the shape of NPs may affect tumor penetration and accumulation.

4.3.1. Effect of Shape on Vessel-Wall Margination. After escaping uptake by the macrophages, NPs should be able to marginate toward the wall of the blood vessels. Spherical NPs tend to remain in the center of the blood flow resulting in a decreased binding rate to the cells, whereas rod-shaped NPs tend to undergo a lateral drift depending on the orientation of their angles of contact $[94,95]$. The tendency for rods to drift may be explained by the variable drag forces and torque forces that are exerted on the rods under flow conditions, which influences their ability to marginate. In fact, discoidal $(\mathrm{AR}=0.5)$, hemisphere, and ellipsoidal particles $(A R=0.5)$ also have higher drift velocities than spheres. For different classes of discoidal particles, the drift velocity increases as the particle aspect ratio deviates further away from unity. Comparing ellipsoids, hemispheres, and discs, it was found that discoidal particles mostly followed highly oscillatory trajectories that led to increased interactions with the vessel wall [96].

4.3.2. Effect of NPs Shape on Binding Capacity. Once NPs succeed in margination to the wall of the blood vessels, they have to be transported to their target site through a combination of binding and diffusion. NPs are able to 


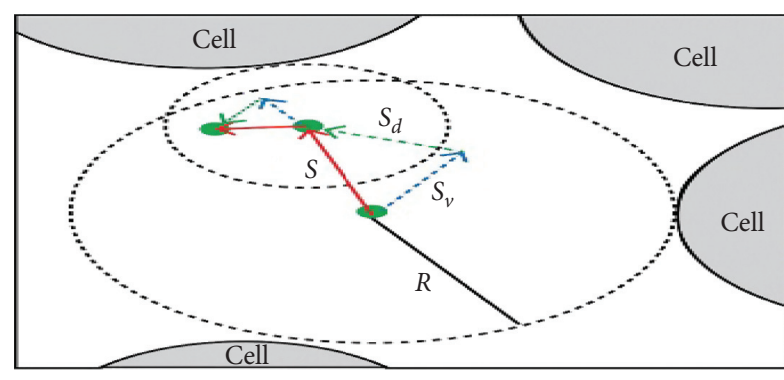

(a)

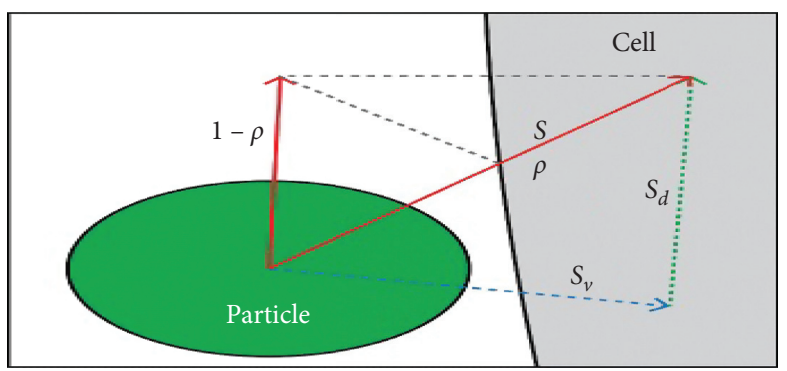

(b)

FIGURE 5: Illustration of the time-adaptive BD algorithm: the green circle represents the NPs, the large gray area represents the cells, and $P$ is the probability of NPs to be captured by the NPs (adapted from [81]; open access no permission required).

TABLE 5: Effect of different shapes of NPs on tumor penetration.

\begin{tabular}{|c|c|c|c|c|}
\hline Author & Nanoparticle type & Nanoparticle shape used & Type of treatment & Efficacy \\
\hline $\begin{array}{l}\text { Agarwal et al. } \\
\text { [85] }\end{array}$ & Gold NPs & $\begin{array}{l}\text { Nanohydrogel; cylindrical; } \\
\text { nanorods; spherical NPs }\end{array}$ & 3D spheroid model & $\begin{array}{c}\text { Better effect of cylindrical hydrogel } \\
\text { NPs }\end{array}$ \\
\hline $\begin{array}{l}\text { Christian et al. } \\
{[86]}\end{array}$ & Micelles & Filamentous and spherical & $\begin{array}{l}\text { Mouse xenograft } \\
\text { tumor }\end{array}$ & $\begin{array}{l}\text { High tumor accumulation of } \\
\text { filamentous }\end{array}$ \\
\hline Lui et al. [87] & $\begin{array}{l}\text { Single-walled carbon } \\
\text { nanotube (SWNT) }\end{array}$ & Carbon nanotubes & Cancer in mice & Tumor targeting effect \\
\hline $\begin{array}{l}\text { Bartczak et al. } \\
\text { [88] }\end{array}$ & Gold NPs & $\begin{array}{l}\text { Spherical, rod, hollow, silica-gold, } \\
\text { core shell }\end{array}$ & $\begin{array}{l}\text { Human endothelial cell } \\
\text { uptake }\end{array}$ & $\begin{array}{l}\text { High cellular uptake for the } \\
\text { spherical and the lowest for the } \\
\text { hollow shapes }\end{array}$ \\
\hline Tak et al. [89] & $\begin{array}{l}\text { Shaped silver NPs } \\
\text { (AgNPs) }\end{array}$ & Rods, spherical, triangular & $\begin{array}{l}\text { Skin permeability in } \\
\text { hairless mice }\end{array}$ & $\begin{array}{r}\text { Nanorods had } \\
\text { penetrati }\end{array}$ \\
\hline $\begin{array}{l}\text { Champion et al. } \\
{[84]}\end{array}$ & $\begin{array}{c}\text { Nonspherical } \\
\text { polystyrene particles }\end{array}$ & Spherical and filamentous & Cancer & $\begin{array}{l}\text { Spherical shapes showed better } \\
\text { tumor homing }\end{array}$ \\
\hline $\begin{array}{l}\text { Champion and } \\
\text { Mitragotri [84] }\end{array}$ & $\begin{array}{l}\text { Non-cross-linked } \\
\text { polystyrene (PS) }\end{array}$ & $\begin{array}{l}\text { Spheres, ellipsoids, elliptical } \\
\text { disks, prolate ellipsoids, } \\
\text { rectangular disks }\end{array}$ & $\begin{array}{l}\text { Uptake by } \\
\text { macrophages } \\
\text { (phagocytosis) }\end{array}$ & $\begin{array}{l}\text { Elongated NPs showed negligible } \\
\text { phagocytosis }\end{array}$ \\
\hline $\begin{array}{l}\text { Kessentini and } \\
\text { Barchiesi [90] }\end{array}$ & Gold NPs & $\begin{array}{l}\text { Nanorods; spheroids; cylinders; } \\
\text { capped cylinders, nanoshells; } \\
\text { hollow nanospheres }\end{array}$ & $\begin{array}{l}\text { Shallow skin cancer } \\
\text { and deeper cancer }\end{array}$ & $\begin{array}{l}\text { (i) Nanospheres for shallow cancer } \\
\text { (ii) Nanospheres and nanorods for } \\
\text { deep cancer }\end{array}$ \\
\hline $\begin{array}{l}\text { Bruckman et al. } \\
\text { [91] }\end{array}$ & $\begin{array}{l}\text { PEGylated tobacco } \\
\text { mosaic virus }\end{array}$ & Nanorods and nanospheres & Blood circulation & $\begin{array}{c}\text { Prolonged circulation of nanorods } \\
\text { better than nanospheres }\end{array}$ \\
\hline Geng et al. [92] & $\begin{array}{l}\text { Paclitaxel-loaded } \\
\text { filomicelles }\end{array}$ & $\begin{array}{l}\text { Spherical and filamentous } \\
\text { (filomicelle) }\end{array}$ & $\begin{array}{l}\text { Blood vessels of rats } \\
\text { and mice }\end{array}$ & Longer circulation of filomicelles \\
\hline Uhl et al. [93] & Polymeric NPs & Sphere, short rod, long rod & $\begin{array}{l}\text { Microfluidic device } \\
\text { (transport in blood } \\
\text { vessel) }\end{array}$ & $\begin{array}{c}\text { Best treatment required } \\
\text { combination of different shaped } \\
\text { NPs administered at different times }\end{array}$ \\
\hline
\end{tabular}

All the studies agreed that nanorods, discoidal, and micelles showed better tumor targeting accumulation and longer circulation. One study found better cellular uptake of spherical NPs compared to other shapes.

accommodate many targeting ligands on their surface, unlike small-molecule drugs [97, 98]. It is very important to note that the binding capacity is influenced by many factors, not only the ligand-binding affinity.

The effect of the NP shape on tumor internalization is somewhat controversial. Some studies report the advantage of rod and cylindrical shaped NPs over other shapes, while, on the contrary, other studies have found better internalization for spherical shapes compared to nonspherical shapes [97, 98].

One important concept should be introduced when we are discussing the binding capacity of NPs, that is, the active fractional area (AFAC). For a sphere, the AFAC is defined as $\left(L-d_{\mathrm{B}}\right) / D_{\mathrm{c}}$ (Figure 6), where $L$ is the length of the ligand; $d_{\mathrm{b}}$ is the binding distance between the NP and the binding site; and $D_{c}$ is the diameter of the NP [99-102]. Spherical NPs have different values of AFAC, whereas particles with equal surface areas have a similar binding capacity (Figure 6).

Gratton et al. [103] found that there was a difference in the internalization of two types of NPs having the same volume: rod-like (depth, $d=150 \mathrm{~nm}$; height, $h=450 \mathrm{~nm}$; volume $\left.=0.00795 \mathrm{~m}^{3}\right)$ and cylindrical counterparts $\left(d=200 \mathrm{~nm}, h=200 \mathrm{~nm}\right.$, and volume $\left.=0.00628 \mathrm{~m}^{3}\right)$. Rod internalization occurred more rapidly and effectively than cylindrical shapes indicating that the shape had an important role in the internalization process [103]. In contrast, Agarwal et al. [85] found that low aspect ratio cylindrical NPs $(H / D \approx 0.3$; disk-like particles, $325 \mathrm{~nm}$ diameter and 


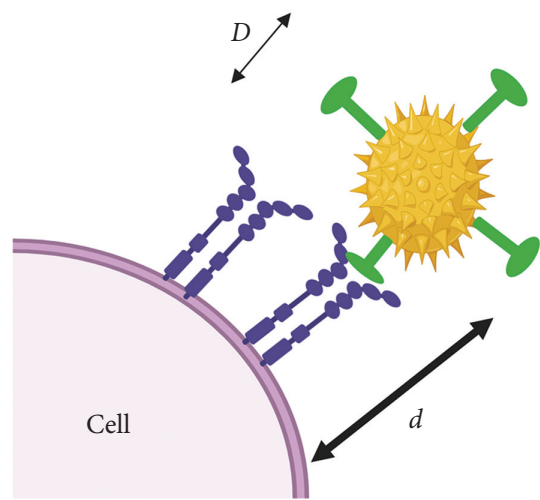

(a)

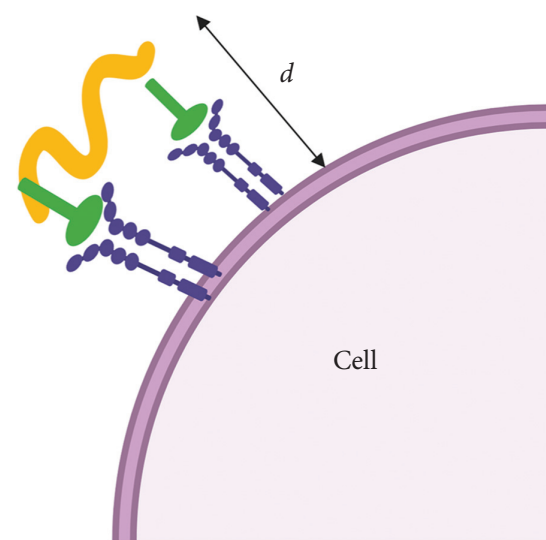

(b)

Figure 6: How different NP shapes could affect the binding avidity of NPs. $d$ is the distance between the receptor and the NP and $D$ is the diameter of the NP.

$100 \mathrm{~nm}$ height) showed a maximal intratissue delivery and a uniform degree of penetration compared to nanorods. They also found that decreasing the aspect ratio and size by increasing the diameter resulted in enhanced delivery efficiency, while for the rods their efficiency was similar, irrespective of their aspect ratio [85]. They suggested that when NPs actually reach the tumor, it is advantageous to have a very low aspect ratio. NP penetration is a balance between several factors: the surface area that allows the particle to interact either actively or passively with the tumor, the contact angle that predicts the rate of internalization.

There is an urgent need to design smart NPs that initially have a high aspect ratio (rod, filamentous, etc.) to achieve better circulation, then to change into a low aspect ratio (spherical shape) when they come into contact with the tumor to achieve better internalization.

4.4. Effect of NPs Charge on Tumor Penetration. Almost all of the components of the tumor microenvironment carry an electrostatic charge. The glycocalyx causes the blood vessels to be slightly negatively charged, whereas the hyaluronic acid existing in the interstitial space and the collagen fibers carry a small positive charge. Consequently, the electrostatic interaction between the tumor microenvironment and the NPs plays an important role in drug delivery [104].

A mathematical model was developed to determine how the NP surface charge affects the transport across the vessel wall [105]. When the pores of the tumor vessel wall are approximately $100 \mathrm{~nm}$, the electrostatic repulsion is negligible, and the transvascular transport of negatively charged NPs is only hindered when the pore size is comparable to the Debye length (distance over which significant charge separation would occur) [105]. The range over which the electrostatic interaction is significant is determined by the Debye length. Electrostatic forces are strong when the Debye length is comparable to the diameter of the pores, because the particle and the electrostatic double layers of the pore are close to each other. An increase in the pore size causes the double layers to separate and only particles that are close to the wall of the cylindrical pore will interact [106].

A new concept relating to charge density has been introduced, in which the charge of the NP is a function of the pore size. Electrostatic attraction that improves transvascular flux is in competition with hydrodynamic and steric interactions [90]; with smaller pores sizes (<100 nm), hydrodynamic and steric forces dominate, and, as a result, the electrostatic interaction is negligible. When the pore size increases, the electrostatic interaction becomes more dominant. [107]; finally, if the pore size is too large $(>300 \mathrm{~nm})$ compared to the NP size, all three types of interaction decrease, and the electrostatic interaction entirely disappears [106].

In order to deliver the appropriate NP to a specific cancer site, a deep understanding of the type of tumor is crucial. For example, in breast cancer, the pore size exceeds $1 \mu \mathrm{m}$ in diameter, while pancreatic and brain tumors have relatively small pore sizes. In addition, a value of surface charge density exists for every NP preparation [107].

Surface charge is another key parameter that determines the NP performance, due to the fact that tumor cells are slightly negatively charged. Therefore, it is considered that positively charged NPs could be taken up better by the cells due to "electrostatic adhesion-mediated targeting" [108, 109].

Neutral or negatively charged NPs may travel for longer distances inside the tumor tissues than positively-charged NPs. Thus a "delayed charge reversal profile" could be a good choice because the tumor penetration could be enhanced without affecting the cellular internalization [42, 110]. Gou et al. [111] found better intratumoral penetration and stronger tumor growth inhibition when preparing NDDS with delayed charge reversal by decorating NP with PGlu-gmPEG at low PH. They monitored the charge by the $E$ potential [111].

Positively charged NPs have been shown to better target tumor vessels, but after extravasation, a switch to a neutral charge allowed more rapid diffusion of the NPs within the tumor tissue [105]. In Table 6, we summarize the effect of NPs charge on tumor uptake. 
TABLE 6: Effect of NPs surface charge on tumor uptake: it seems that positively charged NPs and slightly negative display a good tumor uptake.

\begin{tabular}{|c|c|c|c|}
\hline Authors & Nanoparticle types and charge & Treatment/study & Efficacy \\
\hline Xiao et al. [44] & $\begin{array}{l}\text { NPs with high negative and high } \\
\text { positive charge }\end{array}$ & $\begin{array}{l}\text { Tumor cellular } \\
\text { uptake }\end{array}$ & High uptake of slight negative and slight positive NPs \\
\hline Gou et al. [111] & NPs with different charge & Tumor cell uptake & $\begin{array}{c}\text { Delayed charge reversal strategy could improve } \\
\text { therapeutic effect }\end{array}$ \\
\hline Graf et al. [112] & High positive NPs & $\begin{array}{l}\text { Stability in } \\
\text { physiological media }\end{array}$ & Effective cellular internalization \\
\hline He et al. [45] & $\begin{array}{l}\text { Polymeric NPs negative }(-40 \mathrm{mV}) \\
\text { and positive charge }(+35 \mathrm{mV})\end{array}$ & Tumor uptake & $\begin{array}{c}\text { Slight negative charge accumulate more efficiently in } \\
\text { tumor }\end{array}$ \\
\hline Chen et al. [113] & Positive and negative NPs & Tumor uptake & $\begin{array}{l}\text { High uptake of positively charged Nps increase uptake } \\
\text { of both charge under hypoxic conditions }\end{array}$ \\
\hline $\begin{array}{l}\text { Stylianopoulos } \\
\text { et al. [105] }\end{array}$ & $\begin{array}{l}\text { Positive NPs switched into neutral } \\
\text { inside the tumor }\end{array}$ & $\begin{array}{l}\text { Cancer (tumor } \\
\text { targeting) }\end{array}$ & $\begin{array}{l}\text { Positive NPs: Effective tumor targeting \& neutral charge } \\
\text { allowed quicker diffusion of the nanoparticles to the } \\
\text { tumor tissue }\end{array}$ \\
\hline
\end{tabular}

By referring to Tables 2 and 6, the optimal charge for NPs should initially be neutral for better biodistribution and then switching into cationic or slight negative for selective tumor targeting, moreover, neutral NPs could perform better after entering the tumor tissue.

4.5. NP Surface Coatings and Tumor Penetration. Coating NP is elementary to achieve better circulation time and reduced phagocytosis, whereas, in contact with the tumor tissue, many studies found that PEG may act as an obstacle hindering the interaction of the NPs with the target cells. Some proteins are capable of translocating through the cell membrane efficiently without compromising their integrity $[72,114,115]$. These molecules include cell penetrating peptide (CPP), avidin-biotin, saccharides, and transferrins [116-118]. Tan et al. found that CPP mainly affects transport and exocytosis, whereas PEG polymer influences mucus penetration [119]. Approaches to overcome this limitation while still maintaining the advantages of PEG have been tested, such as preparing PEG covalently linked to 1,2dioleoyl-sn-glycero-3-phosphoethanolamine (DOPE). At low $\mathrm{pH}$ (5-6), the conjugation linkage will be hydrolyzed, leading to fusion with the endosomal membrane and releasing the contents into the cytosol [120].

In a similar approach, Kale and Torchilin [121] prepared TAT (cell penetrating peptide) liposomes with a cleavable PEG coating. When the $\mathrm{pH}$ was reduced to 5 or 6 , the PEG chains will be released, so the TAT will be better internalized by the cancer cells [121].

This promising strategy to improve the penetration capacity of NPs is hampered by the lack of cell specificity and the mode of delivery is not well understood. In an attempt to inhibit the nonspecific interaction of CPP with the blood stream, a novel strategy has been introduced by Ding et al. [118] using ligant-switchable NPS with a hidden CPPs under the PEG corona to avoid direct interaction of immune cells and normal tissue, once they extravasate from the blood vessels the acidic tumor environment would trigger the CPP exposure enabling the diffusion into the tumor [118].
Liu et al. studied the effect of surface charge and the particle size of CPP on cellular internalization. They found that the zeta potential is the key predictor of transduction efficiency, whereas the size of the CPP has a minor effect on cell permeability [122]. More investigations are required to improve their tumor delivery and to reduce their possible side effect [123]. A combination of unconventional electron microscopy technique helps in determining the molecular mass distribution and compositions of dendrimers NPs which helps in assessing the composition, mass, and homogeneity of metal containing organic NPs [124].

In Table 7, we summarize the effect of different NPs coating on tumor penetration.

\section{Discussion}

The major factors that improve the tissue biodistribution of NPs are the physicochemical properties, whereas the major factor that affects the cellular uptake is the coating.

From Tables 1 and 2, it can be concluded that larger NPs (larger surface area) escape the macrophage and RES uptake and circulate for longer times, whereas smaller-sized NPs $(<12 \mathrm{~nm})$ have better tumor uptake. A possible explanation is that although NPs with large surface area can more likely come in contact with the cells, which increase the likelihood of binding, they may not be easily endocytosed by nonspecific cell uptake pathways. Instead, large NPs must be taken up into the cells via an active pathway, which requires the cells to expend more energy to accomplish the task. On the other hand, small NPs do not have much available contact surface area with cells, so adhesion is typically not strong; however, the smaller NPs can be absorbed and taken up by the cells much easier.

In terms of which shape would be best, it can be concluded from Table 3 that to achieve better tissue biodistribution and decrease macrophage uptake, a higher aspect ratio would perform best (particularly for rod and filamentous shapes) compared to other forms. However, for better tumor uptake, it is likely that the best shape depends on the type of cells involved. Tumor uptake of NPs is a dynamic process, which varies as the stage of the tumor 
TABLE 7: Effect of adding different types of coatings to the NPs.

\begin{tabular}{|c|c|c|c|c|c|}
\hline Author & NPs type and size & $\begin{array}{l}\text { Type of added } \\
\text { ligant }\end{array}$ & Treatment & Effect/distribution & Benefit \\
\hline Liu et al. [52] & $\begin{array}{l}\text { Coated BVP-PLA- } \\
\text { NPs } 177 \text { and } \\
319 \mathrm{~nm}\end{array}$ & BVP & IV administration & Liver, spleen, heart, brain & $\begin{array}{l}\text { NPs penetrate the BBB, } \\
\text { avoid the RES, prolong } \\
\text { the half-life of BVP }\end{array}$ \\
\hline $\begin{array}{l}\text { Takeuchi } \\
\text { et al. [51] }\end{array}$ & $\begin{array}{l}\text { Gold NPs 20, } 40 \\
\text { and } 80 \mathrm{~nm}\end{array}$ & PEG & IV administration & $\begin{array}{l}\text { Usefulness of PEG with } \\
\text { smaller NPs size }\end{array}$ & $\begin{array}{l}\text { Reduced accumulation in } \\
\text { liver, spleen, improved } \\
\text { delivery to the brain }\end{array}$ \\
\hline $\begin{array}{l}\text { Ezealisiji and } \\
\text { Okorie [72] }\end{array}$ & Ag NPs & $\begin{array}{l}\text { Peg, PG, Tween, } \\
\text { NaLSo4 }\end{array}$ & $\begin{array}{l}\text { Dermatological } \\
\text { application (skin } \\
\text { penetration) }\end{array}$ & $\begin{array}{l}\text { Maximum penetration efficacy } \\
\text { of NaLSo } 4 \text { followed by PG }\end{array}$ & $\begin{array}{l}\text { Improved skin } \\
\text { penetration }\end{array}$ \\
\hline $\begin{array}{l}\text { Hu et al. } \\
{[125]}\end{array}$ & $\begin{array}{c}\text { PEG-PLA } \\
\text { nanoparticles }\end{array}$ & $\begin{array}{c}\text { Peptide F3 PEG- } \\
\text { PLA } \\
\text { nanoparticles }\end{array}$ & $\begin{array}{l}\text { IV treatment of } \\
\text { glioma }\end{array}$ & $\begin{array}{c}\text { Enhanced accumulation at the } \\
\text { tumor site and deep } \\
\text { penetration into the glioma } \\
\text { parenchyma }\end{array}$ & $\begin{array}{l}\text { Improved parenchyma } \\
\text { penetration }\end{array}$ \\
\hline
\end{tabular}

The maximum penetration was achieved by the NaLSO4 followed by PG and then PEG [105]. Coated BVP-PLA NPs also avoided the RES and prolonged the half-life of NPs [111].

progresses. Uhl et al. [93] concluded that the best shape for transporting drugs across the EC barrier shifted from the larger long rod-shaped NPs to smaller NPs. This occurs because the EC monolayer regains confluency as the tumor regresses, which in turn impedes the transport of the larger NPs [93].

Ideally, a combination of the three different shapes deployed at different times could be the best for getting drugs to the tumor. Specifically, starting with large NPs, which can transport high amounts of the drug early in the treatment time frame, followed by small NPs as the vasculature recovers, and the transport of large bulky NPs becomes increasingly difficult [93].

The key factor that determines the efficacy of passive targeting is the surface area and size of the NPs. Nanoparticles of different sizes behave in a qualitatively different manner. Dqivedi et al. [114] concluded that despite their efforts to enhance hydrophobicity and testing different surface charges, there are cases where larger NPs are totally excluded from cells without any significant NPs uptake [114]. As NPs decrease in size, the physicochemical properties such as surface charge and hydrophobicity become more pronounced.

It seems that the so-called EPR effect is very size-dependent, and it can be slow and not very efficient compared to active targeting [115]. In addition, EPR is also likely to operate in some nontumor vascular beds; it is effective only on well-vascularized primary tumors and ineffective in metastatic disease especially with small metastatic deposits $[115,126]$.

Furthermore, using a mathematical model, Islam et al. [81] found that the NP-cell interactions may moderate the particle size effect. The addition of coatings and surfactants such as peptides (Tat, PEG, and BVB) becomes important in order to achieve an active targeting of NPs that does not rely solely on the EPR effect. Moreover, much effort has gone into the design of molecular ligands such as vitamins, hormones, and growth factors that can be attached to the outside of NPs and which are specifically recognized by receptors on the cancer cells.

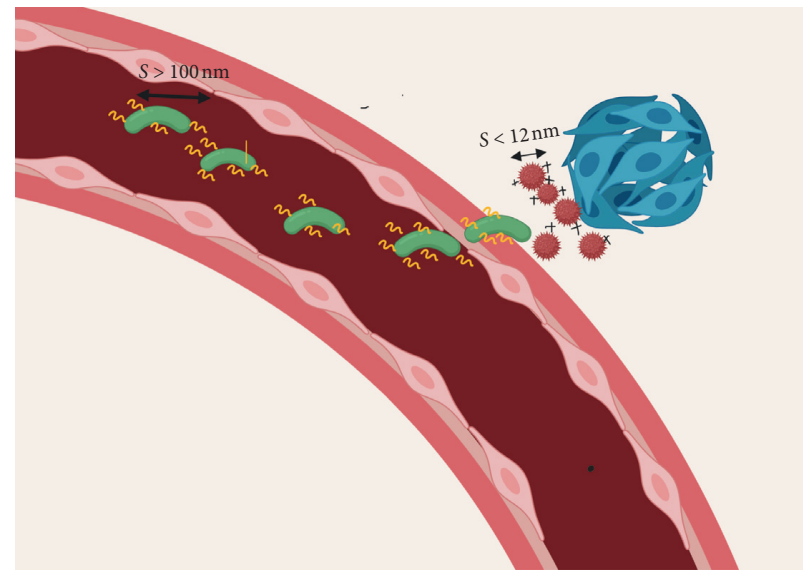

Figure 7: Proposed ideal NPs characteristics. When NPs are in the blood circulation, it is advantageous to have a larger size $(>100 \mathrm{~nm})$ nonspherical shaped NP, with a neutral charge to achieve better circulation and tumor accumulation. Once in contact with the tumor, it is more advantageous to have positively charged or slight negatively charged NPs with a smaller size $(<12 \mathrm{~nm})$ and a lower aspect ratio. The surfactants should be removed once the NPs enter the extracellular matrix (ECM).

A very important point should be noted here is that the addition of coatings and ligands to NPs does not, in itself, have much effect on tissue distribution, which is mainly dependent on the physicochemical properties of the NPs. The ligands and coatings act to improve the intracellular uptake by the target cells and do not necessarily have any effect in improving the tumor targeting $[120,121,127]$. Some studies nowadays discovered the immunogenic properties of PEG which is manifested by the production of anti-PEG antibodies after the first injection of PEG-NPs causing a rapid clearance and ABC phenomenon in the second injection. Novel hydrophilic polymers other than PEG may be a potential alternative choice $[53-55,57,58]$.

Once the NPs succeed in coming in close contact with the target cells, it is more advantageous to remove the 
surfactant coating to achieve better cellular uptake as it has been shown in many studies that the ligands may be an obstacle for effective cellular uptake $[128,129]$.

In Figure 7, we summarize the ideal NP behavior. Ideal NPs should change their physicochemical properties once they have come into close contact with the target cells. These changes could include their size, shape, charge, and coatings. Using an external energy source (laser or heat) [130-132] or taking advantage of internal stimuli $(\mathrm{pH}$ or redox) [133-135] or a tumor feature such as a particular enzyme activity could all be tested to achieve maximum tumor targeting efficacy.

\section{Conclusions}

Smart or stimulus-responsive NPs could allow them to act as a type of "nanorobot," having certain properties while circulating in the blood circulation and changing their properties when they come into contact with the tumor. These changes could include not only the size, but also the shape, the charge, and the coatings.

It seems nowadays that the concept of "one fits all" does not apply anymore. Nanocarriers should be customized to the specific target to achieve the best result. Furthermore, local cancer therapy such as subcutaneous administration starts to be the preferred administration root, since smaller volumes can be injected, meaning lower injection times and shorter hospitalization for patients [136].

Important questions that require answers include what technology we need to safely and precisely manipulate the nanoparticles properties and what is the influence of the administration route on the tumor biodistribution and tumor uptake. Developing effective strategies to modify tumor properties such as degradation of the extracellular matrix is another field to be investigated in the near future.

\section{Abbreviations}

ABC: Accelerated blood clearance
BVP: Breviscapine BVP
CPP: Cell penetrating peptide
ECM: Extracellular matrix
EPR: Enhanced permeability and retention
FDA: Food and Drug Administration
J-FIL: Jet and flash imprint lithography
MPS: Mononuclear phagocytic system
NP: Nanoparticle
PCC: Personalized protein corona
PEG: Polyethylene glycol
PLA: Polylactic acid
QDs: Quantum dots
RES: Reticuloendothelial system
UV: $\quad$ Ultraviolet.

\section{Conflicts of Interest}

The authors declare that they have no conflicts of interest.

\section{References}

[1] Y. Matsumura and H. Maeda, "A new concept for macromolecular therapeutics in cancer chemotherapy: mechanism of tumoritropic accumulation of proteins and the antitumor agent smancs," Cancer Research, vol. 46, no. 12, pp. 63876392, 1986.

[2] I. Maeda and J. Landis, "Can the pharmaceutical industry reduce attrition rates?" Nature Reviews Drug Discovery, vol. 3, no. 8, pp. 711-716, 2004.

[3] R. K. Jain and T. Stylianopoulos, "Delivering nanomedicine to solid tumors," Nature Reviews Clinical Oncology, vol. 7, no. 11, pp. 653-664, 2010.

[4] V. P. Chauhan and R. K. Jain, "Strategies for advancing cancer nanomedicine," Nature Materials, vol. 12, no. 11, pp. 958-962, 2013.

[5] J. Shi, P. W. Kantoff, R. Wooster, and O. C. Farokhzad, "Cancer nanomedicine: progress, challenges and opportunities," Nature Reviews Cancer, vol. 17, no. 1, pp. 20-37, 2017.

[6] H. M. Patel, "Serum opsonin and liposomes: their interaction and opsonoghagocytosis," Critical Reviews in Therapeutic Drug Carrier Systems, vol. 9, pp. 39-90, 1992.

[7] N. Mishra, P. Pant, A. Porwal et al., "Targeted. Drug delivery: a review," American Journal of Pharmtech Research, vol. 6, pp. 2249-3387, 2016.

[8] S. Shukla, A. L. Ablack, A. M. Wen, K. L. Lee, J. D. Lewis, and N. Steinmetz, "Increased tumor homing and tissue penetration of the filamentous plant viral nanoparticle Potato virus $X$," Molecular Pharmaceutics, vol. 10, no. 1, pp. 33-42, 2015.

[9] A. E. Nel, L. Mädler, D. Velegol et al., "Understanding biophysicochemical interactions at the nano-bio interface," Nature Materials, vol. 8, no. 7, pp. 543-557, 2009.

[10] M. Lundqvvist, J. Stigler, G. Elia, I. Lynch, T. Cedervall, and K. A. Dawson, "Nanoparticle size and surface properties determine the protein corona with possible implications for biological impacts," Proceedings of the National Academy of Sciences, vol. 105, no. 38, pp. 14265-14270, 2008.

[11] H. M. Patel, "Serum opsonin and liposomes: their interaction and opsonoghagocytosis," Critical Reviews in Therapeutic Drug Carrier Systems, vol. 9, pp. 39-90, 1992.

[12] Y. Qiu, Y. Liu, L. Wang et al., "Surface chemistry and aspect ratio mediated cellular uptake of Au nanorods," Biomaterials, vol. 31, no. 30, pp. 7606-7619, 2010.

[13] A. Salvati, A. S. Pitek, M. P. Monopoli et al., "Transferrinfunctionalized nanoparticles lose their targeting capabilities when a biomolecule corona adsorbs on the surface," Nature Nanotechnology, vol. 8, no. 2, pp. 137-143, 2013.

[14] M. Hajipour, S. Laurent, A. Aghaie, F. Rezaee, and M. Mahmoudi, "Personalized protein coronas: a "key" factor at the nanobiointerface," Biomaterial Science, vol. 2, no. 9, p. 1210, 2014.

[15] K. Hamad-Schifferli, "Exploiting the novel properties of protein coronas: emerging applications in nanomedicine," Nanomedicine, vol. 10, no. 10, pp. 1663-1674, 2015.

[16] V. Colapicchioni, M. Tilio, L. Digiacomo et al., "Personalized liposome-protein corona in the blood of breast, gastric and pancreatic cancer patients," The International Journal of Biochemistry \& Cell Biology, vol. 75, pp. 180-187, 2016.

[17] L. Treuel and G. U. Nienhaus, "Toward a molecular understanding of nanoparticle-protein interactions," Biophysical Reviews, vol. 4, no. 2, pp. 137-147, 2012.

[18] R. Owen and M. Depledge, "Nanotechnology and the environment: risks and rewards," Marine Pollution Bulletin, vol. 50, no. 6, pp. 609-612, 2005. 
[19] T. Cedervall, I. Lynch, S. Lindman et al., "Understanding the nanoparticle-protein corona using methods to quantify exchange rates and affinities of proteins for nanoparticles," Proceedings of the National Academy of Sciences, vol. 104, no. 7, pp. 2050-2055, 2007.

[20] E. Mahon, A. Salvati, F. Baldelli Bombelli, I. Lynch, and K. A. Dawson, "Designing the nanoparticle-biomolecule interface for "targeting and therapeutic delivery"” Journal of Controlled Release, vol. 161, no. 2, pp. 164-174, 2012.

[21] M. Aoyama, K. Hata, K. Higashisaka, K. Nagano, Y. Yoshioka, and Y. Tsutsumi, "CLusterin in the protein corona plays a key role in the stealth effect of nanoparticles against phagocytes," Biochemical and Biophysical Research Communications, vol. 480, no. 4, pp. 690-695, 2016.

[22] J.-W. Yoo, E. Chambers, and S. Mitragotri, "Factors that control the circulation time of nanoparticles in blood: challenges, solutions and future prospects," Current Pharmaceutical Design, vol. 16, no. 21, pp. 2298-2307, 2010.

[23] H Galley, H. F. Galley and N. R. Webster, Physiology of the endothelium," Journal of Anesthesia, vol. 93, p. 105, 2004.

[24] R. K. Jain, "Transport of molecules in the tumor interstitium: a review," Cancer Research, vol. 47, no. 12, pp. 3039-51, 1987.

[25] R. K. Jain and L. T. Baxter, "Mechanisms of heterogeneous distribution of monoclonal antibodies and other macromolecules in tumors: significance of elevated interstitial," Pressure Cancer Research, vol. 48, p. 7022, 1988.

[26] P. A. Netti, D. A. Berk, M. A. Swartz, A. J. Grodzinsky, and R. K. Jain, "Role of extracellular matrix assembly in interstitial transport in solid tumors," Cancer Research, vol. 60, no. 9, p. 2497, 2000.

[27] G. Sonavane, K. Tomoda, and K. Makino, "Biodistribution of colloidal gold nanoparticles after intravenous administration: effect of particle size," Colloids and Surfaces B: Biointerfaces, vol. 66, no. 2, pp. 274-280, 2008.

[28] S. Hemant, A. S. Kanevsky, H. Wu et al., "Physiologic upper limit of pore size in the blood-tumor barrier of malignant solid tumors," Journal of Translational Medicine, vol. 7, no. 1, p. 51, 2009.

[29] M. Longmire, P. L. Choyke, and H. Kobayashi, "Clearance properties of nano-sized particles and molecules as imaging agents: considerations and caveats," Nanomedicine, vol. 3, no. 5, pp. 703-717, 2008.

[30] S. M. Moghimi, A. C. Hunter, and J. C. Murray, "Longcirculating and target-specific nanoparticles: theory to practice," Pharmacological Reviews, vol. 53, no. 2, pp. 283318, 2001.

[31] W. Gao, K. Xu, L. Ji, and B. Tang, "Effect of gold nanoparticles on glutathione depletion-induced hydrogen peroxide generation and apoptosis in HL7702 cells," Toxicology Letters, vol. 205, no. 1, pp. 86-95, 2011.

[32] X. Li, Z. Hu, J. Ma et al., "The systematic evaluation of sizedependent toxicity and multi-time biodistribution of gold nanoparticles," Colloids and Surfaces B: Biointerfaces, vol. 167, pp. 260-266, 2018.

[33] J Tate, A Petryk, J Hoopes et al., "In vivo biodistribution of iron oxide nanoparticles: an overview," Proceeding of Spie, vol. 7901, Article ID 790117, 2011.

[34] I. Takeuchi, S. Nobato, N. Oiri, K. Tomoda, and K. Makino, "Biodistribution and excretion of colloidal gold nanoparticles after intravenous injection: effects of particle size," Bio-Medical Materials and Engineering, vol. 28, no. 3, pp. 315-323, 2017.

[35] K. Dziendzikowska, J. Gromadzka-Ostroska, A. Krawczynska et al., "Time-dependant biodistrubution and excretion of silver nanoparticles in male Wista rats," Journal of Applied Toxicology, vol. 32, no. 11, pp. 920-928, 2012.

[36] S. Tollis, A. E. Dart, G. Tzircotis, and R. G. Endres, "The zipper mechanism in phagocytosis: energetic requirements and variability in phagocytic cup shape," BMC Systems Biology, vol. 4, no. 1, p. 149, 2010.

[37] R. Toy, P. M. Peiris, K. B. Ghaghada, and E. Karathanasis, "Shaping cancer nanomedicine the effect of particle shape on the in vivo journey of nanoparticles," Nanomedicine, vol. 9, no. 1, pp. 121-134, 2014.

[38] A. Gabizon and D. Papahadjopoulos, "Liposome formulations with prolonged circulation time in blood and enhanced uptake by tumors," Proceedings of the National Academy of Sciences, vol. 85, no. 18, pp. 6949-6953, 1988.

[39] Arnida, M. M. Janat-Amsbury, A. Ray, C. M. Peterson, and H. Ghandehari, "Geometry and surface characteristics of gold nanoparticles influence their biodistribution and uptake by macrophages," European Journal of Pharmaceutics and Biopharmaceutics, vol. 773, no. 3, pp. 417-423, 2011.

[40] S. D. Li and L. Huang, "Pharmacokinetics and biodistribution of nanoparticles," Molecular Pharmaceutics, vol. 5, no. 4, pp. 496-504, 2008.

[41] T. S. Levchenko, R. Rammohan, A. N. Lukyanov, K. Whiteman, and V. P. Rand Torchilin, "Liposome clearance in mice: the effect of a separate and combined presence of surface charge and polymer coating," International Journal of Pharmaceutics, vol. 240, no. 1-2, pp. 95-102, 2002.

[42] J. Hu, S. Miura, K. Na, and Y. H. Bae, "pH responsive and charge shielded cationic micelle of poly (l histidine)-block -short branched PEI for acidic cancer treatment," Journal of Controlled Release, vol. 172, no. 1, pp. 69-76, 2010.

[43] H. Ishiwata, N. Suzuki, S. Ando, H. Kikuchi, and T. Kitagawa, "Characteristics and biodistribution of cationic liposomes and their DNA complexes," Journal of Controlled Release, vol. 69, no. 1, pp. 139-148, 2000.

[44] K. Xiao, Y. Li, J. Luo et al., "The effect of surface charge on in vivo biodistribution of PEG-oligocholic acid based micellar nanoparticles," Biomaterials, vol. 32, no. 13, pp. 3435-3446, 2011.

[45] C. He, Y. Hu, L. Yin, C. Yin, C. Tang, and C. Yin, "Effect of particle size and surface charge on cellular uptake and biodistribution of polymeric nanoparticles," Biomaterial, vol. 31, no. 13, pp. 3657-3666, 2010.

[46] A. P. Walczak, P. J. M. Hendriksen, R. A. Woutersen et al., "Bioavailability and biodistribution of differently charged polystyrene nanoparticles upon oral exposure in rates," Journal of Nanoparticle Research, vol. 17, no. 5, p. 231, 2015.

[47] A. K. Verma and A. Kumar, "Pharmacokinetics and biodistribution of negatively charged pectin nanoparticles encapsulating paclitaxel," Cancer Nanotechnology, vol. 4, pp. 99-102, 2013.

[48] H. Lee, A. H. de Vries, S. J. Marrink, and R. W. Pastor, "A coarse-grained model for polyethylene oxide and polyethylene glycol: conformation and hydrodynamics," The Journal of Physical Chemistry. B, vol. 113, no. 40, pp. 13186-13194, 2009.

[49] L. E. Van Vlerken, T. K. Vyas, and M. M. Amiji, "Poly (ethylene glycol)-modified nanocarriers for tumor-targeted and intracellular delivery," Pharmaceutical Research, vol. 24, no. 8, pp. 1405-1414, 2007.

[50] R. Gref, Y. Minamitake, M. T. Peracchia, V. Trubetskoy, V. Torchilin, and R. Langer, "Biodegradable long-circulating polymeric nanospheres," Science, vol. 263, no. 5153, pp. 1600-1603, 1994. 
[51] I. Takeuchi, H. Onaka, and K. Makino, "Biodistribution of colloidal gold nanoparticles after intravenous injection: effect of PEGylation at the same particle size," Biomedical Materials and Engineering, vol. 29, no. 2, pp. 205-215, 2018.

[52] M. Liu, H. Li, G. Luo, Q. Liu, and Y. Wang, "Pharmacokinetics and biodistribution of surface modification polymeric nanoparticles," Archives of Pharmacal Research, vol. 31, no. 4, pp. 547-554, 2008.

[53] N. M. LaBeck and A. A. Gabizon, "Nanoparticle interactions with the immune system: clinical implications for liposomebased cancer chemotherapy," Frontiers in Immunology, vol. 8, 2017.

[54] H. Ma, K. Shiraishi, T. Minowa et al., "Accelerated blood clearance was not induced for a gadolinium-containingPEGpoly(L-lysine)-based polymeric micelle in mice," Pharmaceutical Research, vol. 27, no. 2, pp. 296-302, 2010.

[55] B. Romberg, C. Oussoren, C. J. Snel, M. G. Carstens, W. E. Hennink, and G. Storm, "Pharmacokinetics of pol$\mathrm{y}$ (hydroxyethyl-1-asparagine)-coated liposomes issuperior over that of PEG-coated liposomes at low lipid dose and upon repeated administration," Biochimica et Biophysica Acta (BBA)_Biomembranes, vol. 1768, no. 3, pp. 737-743, 2007.

[56] S.-Y. Tung, Y.-C. Su, B.-M. Chen et al., "Selective delivery of PEGylated compounds of tumor cells by anti-PEG hybrid antibodies," Molecular Cancer Therapeutics, vol. 14, no. 6, pp. 1317-1326, 2015.

[57] P. Zhang, P. Jain, C. Tsao et al., "Polypeptides with high zwitterion density for safe and effective therapeutics," Angewandte Chemie International Edition, vol. 57, no. 26, pp. 7743-7747, 2018.

[58] Y. Qi, A. Simakova, N. J. Ganson et al., "A brush-polymer/ exendin-4 conjugate reduces blood glucose levels for up to five days and eliminates poly(ethylene glycol) antigenicity," Nature Biomedical Engineering, vol. 1, no. 1, 2016.

[59] Y. Qi and A. Chilkoti, "Protein-polymer conjugation -moving beyond PEGylation," Current Opinion in Chemical Biology, vol. 28, pp. 181-193, 2015.

[60] P. Zhang, F. Sun, C. Tsao et al., "Zwitterionic gel encapsulation promotes protein stability,enhances pharmacokinetics, and reduces immunogenicity," Proceedings of the National Academy of Sciences, vol. 112, no. 39, pp. 1204612051, 2015.

[61] J.-R. Park, J. Guyse, A. Podeyvn, and T. Dargaville, "Influence of side-chain length on long-term release kinetics from poly(2-oxazoline )-drug conjugate networks," European Polymer Journal, vol. 120, Article ID 109217, 2019.

[62] P. L. Rodriguez, T. Harada, D. A. Christian, D. A. Pantano, R. K. Tsai, and D. E. Discher, "Minimal "self" peptides that inhibit phagocytic clearance and enhance delivery of nanoparticles," Science, vol. 339, no. 6122, pp. 971-975, 2013.

[63] J. Kreuter, D. Shamenkov, R. Alyautdin et al., "Apolipoprotein-mediated transport of nanoparticle-bound drugs across the blood-brain barrier," Journal of Drug Targeting, vol. 10, no. 4, pp. 317-325, 2002.

[64] A. Parodi, N. Quattrocchi, A. L. van de Ven et al., "Synthetic nanoparticles functionalized with biomimetic leukocyte membranes possesses cell-like functions," Nature Nanotechnology, vol. 8, no. 1, pp. 61-68, 2013.

[65] C.-M. Hu, L. Zhang, S. Aryal, C. Cheung, R. H. Fang, and L. Zhang, "Erythrocyte membrane-camouflaged polymeric nanoparticles as a biomimetic delivery platform," Proceedings of the National Academy of Sciences, vol. 108, no. 27, pp. 10980-10985, 2011.
[66] A. S. A. Lila, K. Nawata, T. Shimizu, T. Ishida, and H. Kiwada, "Use of polyglycerolm (PG), instead of polyethylene glycol (PEG), prevents induction of the accelerated blood clearance phenomenon against long-circulating liposomesupon repeated administration," International Journal of Pharmaceutics, vol. 456, no. 1, pp. 235-242, 2013.

[67] H. Sarin, "Physiologic upper limits of pore size of different blood capillary types and another perspective on the dual pore theory of microvascular permeability," Journal of Angiogenesis Research, vol. 2, no. 1, p. 14, 2010.

[68] F. Yuan, H. A. Salehi, Y. Boucher, U. S. Vasthare, and J. R. K. Tuma, "Vascular permeability and microcirculation of gliomas and mammary carcinomas transplanted in rat and mouse cranial windows," Cancer Research, vol. 54, no. 17, pp. 4564-4568, 1994.

[69] H. Wiig and M. A. Swartz, "Interstitial fluid and lymph formation and transport: physiological regulation and roles in inflammation and cancer," Physiological Reviews, vol. 92, no. 3, pp. 1005-1060, 2012.

[70] V. P. Chauhan, T. Stylianopoulos, J. D. Martin et al., "Normalization of tumour blood vessels improves the delivery of nanomedicines in a size-dependent manner," $\mathrm{Na}$ ture Nanotechnology, vol. 7, no. 6, pp. 383-388, 2012.

[71] H. Cabral, Y. Matsumoto, K. Kataoka et al., "Accumulation of sub-100 nm polymeric micellsin poorly permeable tumours depends on size," Nature Nanotechnology, vol. 6, no. 12, pp. 815-823, 2011.

[72] K. M. Ezealisiji and H. N. Okorie, "Size dependent skin penetration of silver nanoparticles: effect of penetration enhancers," Applied Nanoscience, vol. 8, no. 8, pp. 20392046, 2019.

[73] Z. Popović, W. Liu, V. P. Chauhan et al., "A nanoparticle size series for in vivo fluorescence imaging," Angewandte Chemie, vol. 122, no. 46, pp. 8649-8652, 2010.

[74] G. S. Terentyuk, G. N. Maslyakova, L. V. Suleymanova et al., "Circulation and biodistribution of gold nanoparticles and induced alterations of tissue morphology at intravenous particle delivery," Biophotonics, vol. 2, no. 5, pp. 292-302, 2009.

[75] C. Wong, T. Stylianopoulos, J. Cui et al., "Multistage nanoparticle delivery system for deep penetration into tumor tissue," Proceedings of the National Academy of Sciences, vol. 108, no. 6, pp. 2426-2431, 2011.

[76] R. Tong, H. D. Hemmati, R. Langer, and D. S. Kohane, "Photoswitchable nanoparticles for triggered tissue penetration and drug delivery," Journal of the American Chemical Society, vol. 134, no. 21, pp. 8848-8855, 2012.

[77] R. R. Arvizo, R. Subinoy, O. R. Miranda, R. Bhattacharya, V. M. Rotello, and P. Mukherjee, "Mechanism of anti-angiogenic property of gold nanoparticles: role of nanoparticle size and surface charge," Nanomedicine: Nanotechnology, Biology and Medicine, vol. 7, no. 5, pp. 580-587, 2011.

[78] V. Peretz, M. Motiei, C. N. Sukenik, and R. Popovtzer, "The effect of nanoparticle size on cellular binding probability," Journal of Atomic, Molecular, and Optical Physics, vol. 2012, Article ID 404536, 7 pages, 2012.

[79] J. Huang, L. Bu, J. Xie et al., "Effects of nanoparticle size on cellular uptake and liver MRI with polyvinylpyrrolidonecoated iron oxide nanoparticles," ACS Nano, vol. 4, no. 12, pp. 7151-7160, 2010.

[80] K. Huang, H. Ma, J. Liu et al., "Size-dependent localization and penetration of ultrasmall gold nanoparticles in cancer cells, multicellular spheroids, and tumors in vivo," ACS Nano, vol. 6, no. 5, pp. 4483-4493, 2012. 
[81] M. A. Islam, S. Barua, and D. Barua, "A multiscale modeling study of particle size effects on the tissue penetration efficacy of drug-delivery nanoparticles," BMC Systems Biology, vol. 11, no. 1, p. 113, 2017.

[82] J. A. Champion, Y. K. Katare, and S. Mitragotri, "Making polymeric micro- and nanoparticles of complex shapes," Proceedings of the National Academy of Sciences, vol. 104, no. 29, Article ID 11901, 2007.

[83] R. Agarwal, V. Singh, P. Jurney, L. Shi, S. V. Sreenivasan, and K. Roy, "Scalable imprinting of shape-specific polymeric nanocarriers using a release layer of switchable water solubility,” ACS Nano, vol. 6, no. 3, pp. 2524-2531, 2012.

[84] J. A. Champion and S. Mitragotri, "Shape induced inhibition of phagocytosis of polymer particles," Pharmaceutical Research, vol. 26, no. 1, pp. 244-249, 2009.

[85] R. Agarwal, P. Jurney, M. Raythatha et al., "Effect of shape, size and aspect ratio on nanoparticle penetration and distribution inside solid tissues using 3D spheroid models," Advanced Healthcare Materials, vol. 4, no. 15, pp. 2269-2280, 2015.

[86] D. A. Christian, S. Cai, O. B. Garbuzenko et al., "Flexible filaments for in vivo imaging and delivery: persistent circulation of filomicelles opens the dosage window for sustained tumor shrinkage," Molecular Pharmaceutics, vol. 6, no. 5, pp. 1343-1352, 2009.

[87] Z. Liu, W. Cai, L. He et al., "In vivo biodistribution and highly efficient tumour targeting of carbon nanotubes in mice," Nature Nanotechnology, vol. 2, no. 1, pp. 47-52, 2007.

[88] D. Bartczak, O. L. Muskens, S. Nitti, T. Sanchez-Elsner, T. M. Millar, and A. G. Kanaras, "Interactions of human endothelial cells with gold nanoparticles of different morphologies," Small, vol. 8, no. 1, pp. 122-130, 2012.

[89] Y. K. Tak, S. Pal, P. K. Naoghare, S. Rangasamy, and J. Myong Song, "Shape-dependant skin penetration of silver nanoparticle: does it really matter," Scientific Reports, vol. 5, no. 1, Article ID 16908, 2015.

[90] S. Kessentini and D. Barchiesi, "Quantitative comparison of optimized nanorods, nanoshells and hollow nanospheres for photothermal therapy," Biomedical Optics Express, vol. 3, no. 3, pp. 590-604, 2012.

[91] M. A. Bruckman, L. N. Randolph, A. VanMeter et al., "Biodistribution,pharmacokinetics, and blood compatibility of native and PEGylated tobacco mosaic virus nano-rods and-spheres in mice," Virology, vol. 449, pp. 163-173, 2014.

[92] Y. Geng, P. Dalhaimer, S. Cai et al., "Shape effects of filaments versus spherical particles in flow and drug delivery," Nature Nanotechnology, vol. 2, no. 4, pp. 249-255, 2007.

[93] C. G. Uhl, Y. Gao, S. Zhou, and Y. Liu, "The shape effect on polymer nanoparticle transport in a blood vessel," RSC Advances, vol. 8, no. 15, pp. 8089-8100, 2018.

[94] E. Gavze and M. Shapiro, "Particles in a shear flow near a solid wall: effect of non sphericity on forces and velocities," International Journal of Multiphase Flow, vol. 23, no. 1, pp. 155-182, 1996.

[95] J. Park and J. E. Butler, "Analysis of the migration of rigid polymers and nanorods in a rotating viscometric flow," Macromolecules, vol. 43, no. 5, pp. 2535-2543, 2010.

[96] S.-Y. Lee, M. Ferrari, and P. Decuzzi, "Shaping nano-/microparticles for enhanced vascular interaction in laminar flows," Nanotechnology, vol. 20, no. 49, Article ID 495101, 2008.

[97] B. D. Chithrani, A. A. Ghazani, and W. C. Chan, "Determining the size and shape dependence of gold nanoparticle uptake into mammalian cells," Nano Letters, vol. 6, no. 4, pp. 662-668, 2006.
[98] K. Zhang, H. Fang, Z. Chen, J. S. Taylor, and K. L. Wooley, "Shape effects of nanoparticles conjugated with cell-penetrating peptides (HIV Tat PTD) on CHO cell uptake," Bioconjugate Chemistry, vol. 19, no. 9, pp. 1880-1887, 2008.

[99] A. J. Calderon, T. Bhowmick, J. Leferovich et al., "Optimizing endothelial targeting by modulating the antibody density and particle concentration of anti-ICAM coated carriers," Journal of Controlled Release, vol. 150, no. 1, pp. 37-44, 2011.

[100] J. M. Saul, A. Annapragada, J. V. Natarajan, and R. V. Bellamkonda, "Controlled targeting of liposomal doxorubicin via the folate receptor in vitro," Journal of Controlled Release, vol. 92, no. 1-2, pp. 49-67, 2003.

[101] C. Rangger, A. Helbok, E. Von Guggenberg et al., "Influence of PEGylation and RGD loading on the targeting properties of radiolabeled liposomal nanoparticles," International Journal of Nanomedicine, vol. 7, pp. 5889-5900, 2012.

[102] P. Decuzzi and M. Ferrari, "The receptor-mediated endocytosis of nonspherical particles," Biophysical Journal, vol. 94, no. 10, pp. 3790-3797, 2008.

[103] S. E. A. Gratton, P. A. Ropp, P. D. Pohlhaus et al., "The effect of particle design on cellular internalization pathways," Proceedings of the National Academy of Sciences, vol. 105, no. 33, Article ID 11613, 2008.

[104] Y. H. Lahir, "Understanding the basic role of glycocalyx during cancer," Journal of Radiation and Cancer Research, vol. 7, no. 3, pp. 79-84, 2016.

[105] T. Stylianopoulos, M.-Z. Poh, N. Insin et al., "Diffusion of particles in the extracellular matrix: the effect of repulsive electrostatic interactions electrostatic interactions," Biophysical Journal, vol. 99, no. 5, pp. 1342-1349, 2010.

[106] T. Stylianopoulos, K. Soteriou, D. Fukumura, and R. K. Jain, "Cationic nanoparticles have superior transvascular flux into solid tumors: insights from a mathematical model," Annals of Biomedical Engineering, vol. 41, no. 1, pp. 68-77, 2013.

[107] S. K. Hobbs, W. L. Monsky, F. Yuan et al., "Regulation of transport pathways in tumor vessels: role of tumor type and microenvironment," Proceedings of the National Academy of Sciences, vol. 95, no. 8, pp. 4607-4612, 1998.

[108] H. Zhang, X. Kong, Y. Tang, and W. Lin, "Hydrogen sulfide triggered charge reversal micells of cancer targeted drug delivery and imaging," ACS Applied Materials \& Interfaces, vol. 8, no. 25, pp. 16227-16239, 2016.

[109] T. Ji, Y. Ding, Y. Zhao et al., "Peptide assembly integration of fibroblast-targeting of fibroblast-targeting and cell-penetration features for enhanced anti-tumor drug delivery," Advanced Materials, vol. 27, no. 11, pp. 1865-1873, 2015.

[110] F. Alexis, E. Pridgen, L. K. Molnar, and O. C. Farokhzad, "Factors affecting the clearance and distribution of polymeric nanoparticles," Molecular Pharmaceutics, vol. 5, no. 4, pp. 505-515, 2008.

[111] J. Gou, Y. Liang, and L. Miao, "Improved tumor tissue penetration and tumor cell uptake achieved by delayed charge reversal nanoparticles," Acta Biomaterialia, vol. 62, pp. 157-166, 2017.

[112] C. Graf, Q. Gao, I. Schutz et al., "Surface functionalization of silica nanoparticles supports colloidal stability in physiological media and facilitates internalization in cells," Langmuir, vol. 28, no. 20, pp. 7598-7613, 2012.

[113] Z. Chen, F. Wang, and L. Zhu, "The effects of hypoxia on uptake of positively charged nanoparticles by tumor cells," Journal of Bionanoscience, vol. 7, no. 5, pp. 601-605, 2013.

[114] M. V. Dqivedi, R. K. Harischandra, O. Koshkina, and H.-J. Galla, "Size influence the effect of hydrophobic 
nanoparticles on lung surfactant model system," Biophysical Journal, vol. 106, no. 1, pp. 289-298, 2014.

[115] K. Lyer, G. Khaled, J. Fang, and H. Maeda, "Exploiting the enhanced permeability and retention effect for tumor targeting," Drug Discovery Today, vol. 11, no. 17-18, pp. 812-818, 2006.

[116] S. Silva, A. Almeida, and N. Vale, "Combination of cellpenetrating peptides with nanoparticles for therapeutic application," Biomolecule, vol. 9, no. 1, p. 22, 2017.

[117] D. P. Gaspar, V. Faria, J. P. Quintas, and A. J. Almeida, "Targeted delivery of lipid nanoparticles by means of surface chemical modification," Current Organic Chemistry, vol. 21, no. 23, pp. 2360-2375, 2017.

[118] Y. Ding, J. Liu, Y. Zhang, L. Shi et al., "A novel strategy based on a ligant-switchable nanoparticle delivery system for deep tumor penetration," Nanoscale Horizons, vol. 4, no. 3, pp. 658-666, 2019.

[119] X. Tan, Y. Zhang, Q. Wang et al., "Cell penetrating peptide together with PEG-modified mesostructured silica nanoparticles promotes mucous permeation and oral delivery of therapeutic proteins and peptides," Biomaterials Science, vol. 7, no. 7, pp. 2934-2950, 2019.

[120] V. P. Torchilin, S. Levchenko, K. R. Whiteman et al., "p Nitrophenylcarbonyl-PEG-PE-liposomes: fast and simple attachment of specific ligands, including monoclonal antibodies, to distal ends of PEG chains via p-nitrophenylcarbonyl groups," Biochimica et BiophysicaActa (BBA)-Biomembranes, vol. 1511, no. 2, pp. 397-411, 2001.

[121] A. A. Kale and V. L. Torchilin, "Smart drug carriers: PEGylated TATp-modified pH-sensitive liposomes," Journal of Liposome Research, vol. 17, no. 3-4, pp. 197-203, 2007.

[122] B. R. Liu, M. H. Chan, H. J. Lee et al., "Effect of surface charge and particle size of cell-penetrating peptide/nanoparticle complexes on cellular internalization," Cell Membrane USA: Nova Science, vol. 31, pp. 43-57, 2013.

[123] P. Couvreur, "Nanoparticles in drug delivery: past, present and future," Advanced Drug Delivery Reviews, vol. 65, no. 1, pp. 21-23, 2013.

[124] A. A. Sousa, M. A. Aronova, H. Wu, H. Sarin, G. L. Griffiths, and R. D. Leapman, "Determining molecular mass distribution and composition of functionalized dendrimer nanoparticles," Nanomedicine, vol. 4, no. 4, pp. 391-399, 2009.

[125] Q. Hu, G. Gu, Z. Liu et al., "F3 peptide-functionalized PEGPLA nanoparticles co-administrated with tLyp-1 peptide for anti-glioma drug delivery," Biomaterials, vol. 34, no. 4, pp. 1135-1145, 2013.

[126] Y. L. Su and S. H. Hu, "Functional nanoparticles for tumor penetration of therapeutics," Pharmaceutics, vol. 10, no. 4, p. 193, 2018.

[127] D. W. Bartlett, H. Su, I. J. Hildebrandt, W. A. Weber, and M. E. Davis, "Impact of tumor-specific targeting on the biodistribution and efficacy of siRNA nanoparticlesmeasured by multimodality in vivo imaging," Proceedings of the National Academy of Sciences, vol. 104, no. 39, pp. 15549-15554, 2007.

[128] X. Guo and J. R. Szoka, "Steric stabilization of fusogenic liposome by a low PH sensitive PEG-diortho ester lipid conjugates," Bioconjugate Chemistry, vol. 12, no. 2, pp. 291-300, 2001.

[129] A. A. Kale and V. P. Torchilin, "Enhanced transfection of tumor cells in vivo using "smart" PH sensitive TAT modified pegylated liposomes," Journal of Drug Targeting, vol. 15, no. 7-8, pp. 538-545, 2007.
[130] M. R. Younis, C. Wang, X. H. Xia et al., "Low power single laser activated synergistic cancer phototherapy using photosensitizer functionalized dual plasmonic photothermal nanoagents," ACs Nano, vol. 13, pp. 254-2557, 2019.

[131] X. Zhen, P. Cheng, and K. Pu, "Cancer phototherapy: recent advances in cell membrane-camouflaged nanoparticles for cancer phothotherapy," Small, vol. 15, no. 1, Article ID 1804105, 2019.

[132] R. Zein, W. Selting, and M. Hamblin, "Light parameters and photobiomodulation: dive into complexity," Journal of Biomedical Optics, vol. 23, pp. 120901-120917, 2018.

[133] M. Karimi, A. Ghasemi, M. Hamblim et al., "Smart micro/ nanoparticles in stimulus-responsive drug/gene delivery systems," Chemical Society Reviews, vol. 45, no. 5, pp. 1457-1501, 2016.

[134] X. Wang, M. Zhang, L. Zhang et al., "Designed synthesis of lipid-coated polyacrylic acid/calcium phosphate nanoparticles as dual $\mathrm{pH}$-responsive drug-delivery vehicles for cancer chemotherapy," Chemistry-A European Journal, vol. 23, no. 27, pp. 6586-6595, 2017.

[135] S. Naz, M. Shamoon, R. Wang, L. Zhang, J. Zhou, and J. Chen, "Advances in therapeutic implications of inorganic drug delivery nano-platforms for cancer," International Journal of Molecular Sciences, vol. 20, no. 4, p. 965, 2019.

[136] M. Liu, P. Huamg, W. Wang et al., "An injectable nanocomposite hydrogel co-constructed with gold nanorod and paclitaxel-loaded nanoparticles for local chemo-photothermal synergetic cancer therapy," Journal of Materials Chemistry, vol. 7, no. 16, pp. 2667-2677, 2019. 